\title{
Salinity tolerance mechanisms in glycophytes: An overview with the central focus on rice plants
}

\author{
Tomoaki Horie ${ }^{1 *}$, Ichirou Karahara ${ }^{2}$ and Maki Katsuhara ${ }^{3}$
}

\begin{abstract}
Elevated $\mathrm{Na}^{+}$levels in agricultural lands are increasingly becoming a serious threat to the world agriculture. Plants suffer osmotic and ionic stress under high salinity due to the salts accumulated at the outside of roots and those accumulated at the inside of the plant cells, respectively. Mechanisms of salinity tolerance in plants have been extensively studied and in the recent years these studies focus on the function of key enzymes and plant morphological traits. Here, we provide an updated overview of salt tolerant mechanisms in glycophytes with a particular interest in rice (Oryza sativa) plants. Protective mechanisms that prevent water loss due to the increased osmotic pressure, the development of $\mathrm{Na}^{+}$toxicity on essential cellular metabolisms, and the movement of ions via the apoplastic pathway (i.e. apoplastic barriers) are described here in detail.
\end{abstract}

\section{Background}

The global climate change is feared to promote rapid soil degradations in agricultural lands worldwide. Soil salinization is one of the serious soil degradations, which can arise from natural causes and human-mediated activity such as irrigation in arid and semi-arid regions. Approximately $20 \%$ of the irrigated lands in the world are presumably affected by soil salinization (Yeo 1999). Salinity stress significantly reduces growth and productivity of glycophytes, which are the majority of agricultural products. The term "salinity" represents all the problems of the soil accumulating excessive salts, which can be categorized into sodic (or alkaline) and saline soils (IRRI 2011). Sodic soils having a poor soil structure generally spread over arid and semi-arid regions, retaining high concentrations of $\mathrm{Na}^{+}$at the exchangeable site of clay particles in the soil, which shows high $\mathrm{pH}$ (greater than 8.5) with a high exchangeable sodium percentage (ESP > 15) (IRRI 2011). Saline soils can be generally found in arid regions, estuaries, and coastal fringes, which are dominated by $\mathrm{Na}^{+}$ions with electrical conductivity (EC) more than $4 \mathrm{dS} / \mathrm{m}$ that corresponds to approximately $40 \mathrm{mM} \mathrm{NaCl}$ (IRRI 2011; Munns and Tester 2008). Moreover, saline soils exhibit ESP of $<15$

\footnotetext{
* Correspondence: horie@shinshu-u.ac.jp

'Division of Applied Biology, Faculty of Textile Science and Technology,

Shinshu University, 3-15-1, Tokida, Ueda, Nagano 386-8567, Japan

Full list of author information is available at the end of the article
}

and much lower $\mathrm{pH}$ values than the sodic soils (IRRI 2011).

Plants have to cope with two major stresses under high salinity, osmotic stress and ionic stress (Figure 1). The former stress immediately comes over plants in accordance with a rise in salt levels outside the roots, which leads to inhibitions of water uptake, cell expansion and lateral bud development (Figure 1) (Munns and Tester 2008). The latter stress phase develops later when toxic ions such as $\mathrm{Na}^{+}$accumulate in excess in plants particularly in leaves over the threshold, which leads to an increase in leaf mortality with chlorosis and necrosis, and a decrease in the activity of essential cellular metabolisms including photosynthesis (Figure 1) (Yeo and Flowers 1986; Glenn et al. 1999). Recent molecular physiological and molecular genetic studies have increasingly gained knowledge for the protection mechanisms that plants use to cope with detrimental effects of salinity stress (Blumwald 2000; Zhu 2002; Pardo et al. 2006; Munns and Tester 2008; Horie et al. 2009; Hauser and Horie 2010). Many studies also highlight the significance and relevancy of the functions/regulations of important membrane proteins such as water channels and $\mathrm{Na}^{+}$ transporters (Horie and Schroeder 2004; Maurel et al. 2008; Ward et al. 2009) and also signaling molecules (Zhu 2002) to plant salt tolerance.

In this review, we summarize the problems caused by soil salinity and molecular mechanisms that protect plants from salinity stress, combining knowledge from 


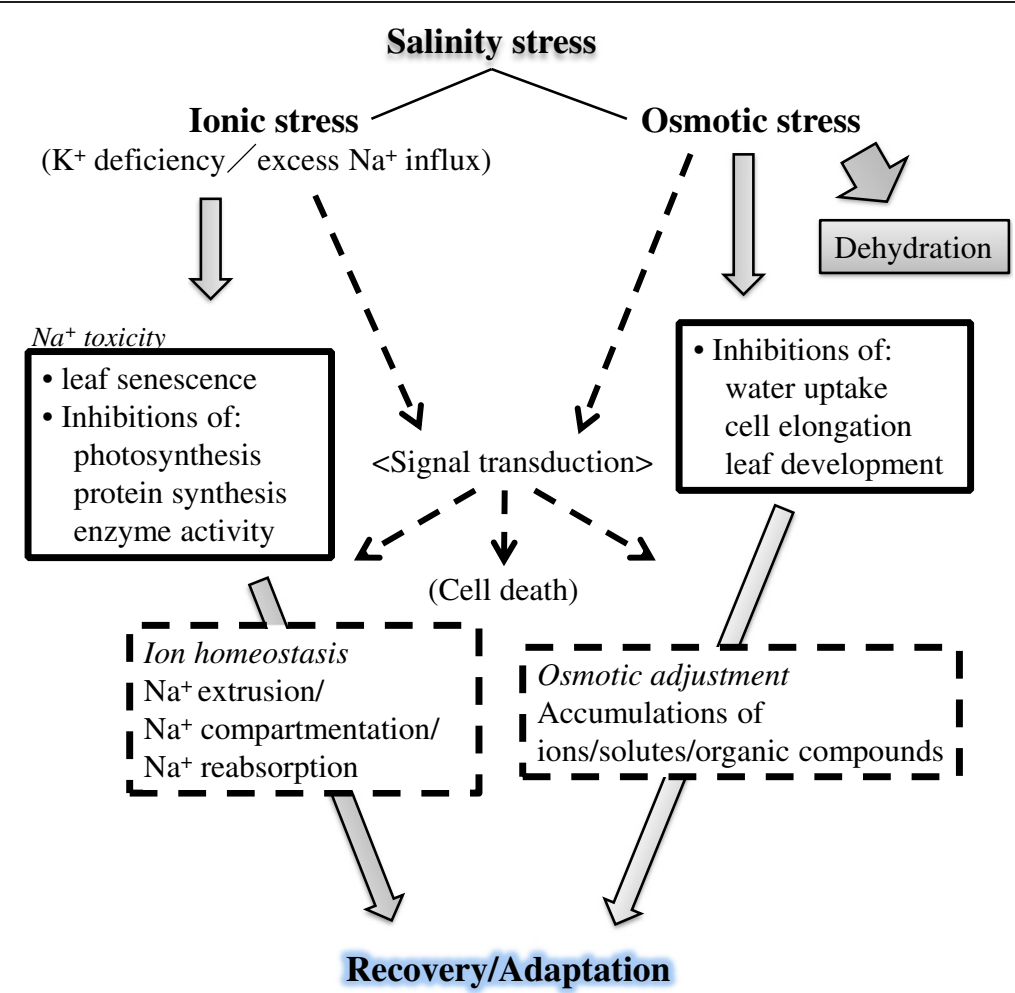

Figure 1 A schematic summary of the stresses that plants suffer under high salinity growth condition and the corresponding responses that plants use in order to survive these detrimental effects.

classic physiology with the recent findings. Rice is the most salt sensitive among cereals (Munns and Tester 2008). In rice, it has been observed that the rate of $\mathrm{Na}^{+}$ uptake into shoots mediated by the intrusive apoplastic ion transport is considerably high under salinity stress (Yeo et al. 1987; Yadav et al. 1996; Ochiai and Matoh 2002). Therefore, in addition to the first two sections where responses of plants to osmotic stress and ionic stress are mentioned, we particularly highlight morphological traits/barriers of plant roots under salinity stress in the last section of this review. Current achievements of investigators and future prospects are discussed.

\section{Responses to osmotic stress caused by high salinity}

Salinity-induced osmotic stress reduces water uptake into plant roots. Plants regulate water transport under salinity stress because a sufficient amount of water is indispensable for the cells to maintain their growth and vital cellular functions such as photosynthesis and metabolisms. In the long distance water transport from roots to shoots, evaporation is one of the main motive forces for the water movement, especially in the apoplastic pathway. Salinity/osmotic stress directly (Yeo et al. 1985) or indirectly via hormonal regulation (Jia et al. 2002) induces a stomatal closure, which leads to a reduction in the evaporation and overall water transport.
Along with the apoplastic pathway, symplastic and transcellular pathways are also important in water transport in plants. In these pathways, where the water is transported across the membrane, the water potential $(\Psi)$ plays a central role in the driving force for the water movement. Although some theoretical issue regarding a biological cause of the water flux remains to be discussed (Kramer and Boyer 1985), water flux is positively correlated with the product of water potential difference $(\Delta \Psi)$ and hydraulic permeability $(L \mathrm{p})$. In case of water uptake in root cells, $\Delta \Psi$ is the difference between $\Psi$ of extracellular solution and intracellular sap solution. Under non-stress condition, intracellular $\Psi$ is generally more negative than that of the soil solution, resulting in water influx into roots according to the water potential gradient. The water potential $(\Psi)$ is approximately consistent with the sum of the pressure potential $\left(\Psi_{\mathrm{p}}\right)$ and the osmotic potential ( $\Psi_{\text {osm }}$, equivalent to the osmotic pressure of salt solution but with minus sign because they work in opposite direction).

Because of dissolved ions that decrease extracellular $\Psi_{\text {osm }}$, salinity stress immediately reduces $\Delta \Psi$ thus water influx. If the water potential gradient is reversed due to severe salinity/osmotic stress (that is, an excessive amount of dissolved ions decreases extracellular $\Psi_{\text {osm }}$ remarkably), water efflux from roots (dehydration) can 
occur. To minimize the influence of a reduction in water influx or dehydration upon the growth under salinity/osmotic stress, plants set independent strategies in motion by regulating the root $L \mathrm{p}\left(L \mathrm{p}_{\mathrm{r}}\right)$ and attempting to restore $\Delta \Psi$ (Figure 2). Active regulation of intracellular $\Psi_{\text {osm }}$, which re-establishes $\Delta \Psi$, can be achieved by accumulating solutes including organic compounds (for details, see below). However, time is required ( $>$ several hours or days) to accumulate enough solutes inside the cell to get a decrease in intracellular $\Psi_{\text {osm }}$ (osmotic adjustments). Signal transduction and changes of related-gene expression, in contrast, are a relatively quick response (Figure 2). Fine-tuning of $L \mathrm{p}_{\mathrm{r}}$ that occurs within hours is important for adaptive regulation under salinity/osmotic stress. Several days after the salinity/osmotic stress, the whole-root water conductance can also be regulated by increasing the total root surface area via changes in the root morphology because the whole-root water conductance is the product of $L \mathrm{p}_{\mathrm{r}}$ by the total root surface area. For example, a stimulation of the lateral root formation was observed in Arabidopsis thaliana under mild salt stress (Zolla et al. 2010). In rice, increased growth of roots in depth was found under drought stress (Asch et al. 2005), but the detailed response of rice roots to drought or salinity stress is yet to be elucidated.

\section{Regulations of $L p_{r}$ and aquaporin water channels}

Intracellular $\Psi$ of cells with full turgor of maize (Zea mays) or wheat (Triticum aestivum) was reported to be in a range of 0.5-0.7 MPa (Munns, 2002). Consistently, the corresponding $\Psi$ of rice root cells was measured to be $-0.5 \mathrm{MPa}$ (Katsuhara, unpublished data). Osmotic $\Psi$ of $-0.5 \mathrm{MPa}$ is equivalent to a $220 \mathrm{mOsm}$ solution or a $124 \mathrm{mM} \mathrm{NaCl}$ solution, which means $\Delta \Psi$ is reduced but not eliminated by salinity stress of $100 \mathrm{mM} \mathrm{NaCl}$ or less. Under such circumstances, an enhancement of $L \mathrm{p}_{\mathrm{r}}$ might compensate the reduction of water influx. As a matter of fact, however, reductions in $L \mathrm{p}_{\mathrm{r}}$ were recorded in several plant species including Arabidopsis and maize under salinity stress of less than $100 \mathrm{mM} \mathrm{NaCl}$ (Azaizeh and Steudle 1991; Peyrano et al. 1997; Carvajal et al. 1999; Martínez-Ballesta et al. 2000; Martínez-Ballesta et al. 2003; Boursiac et al. 2005). In roots of barley (Hordeum vulgare) seedlings, no significant change in the $L \mathrm{p}_{\mathrm{r}}$ has been reported when plants were treated with $100 \mathrm{mM}$ $\mathrm{NaCl}$ for $4 \mathrm{hrs}$ in a sharp contrast to the severe $L \mathrm{p}_{\mathrm{r}}$ repression by $200 \mathrm{mM} \mathrm{NaCl}$ treatments for $4 \mathrm{hrs}$ (Horie et al. 2011b). However, more detailed time course $L p_{r}$ analyses using barley seedlings imposed by $100 \mathrm{mM} \mathrm{NaCl}$ stress demonstrated that severe $L \mathrm{p}_{\mathrm{r}}$ repression occurs within $1 \mathrm{hr}$ and the repression status lasts at least for $24 \mathrm{hrs}$ with a complex temporal $L p_{r}$ retrieval (Kaneko, Horie and Katsuhara, unpublished). Such $L \mathrm{p}_{\mathrm{r}}$ reductions should be effective to prevent dehydration under stress conditions more severe than $-0.5 \mathrm{MPa}$ (i.e. equivalent to $124 \mathrm{mM}$ or more of $\mathrm{NaCl}$ ). Severe salinity stress markedly decreases $\Psi$ of the soil solution, which can reverse the osmotic gradient between the inside and the outside of root cell, which generates water efflux (dehydration). In these conditions, shutdown of the water transport attributed to the $L \mathrm{p}_{\mathrm{r}}$ reduction should be essential to minimize water loss at the initial phase of severe salt stress for survival (Kjellbom et al. 1999; Hachez et al. 2006; Horie et al. 2011b). However, the reason why $\mathrm{NaCl}$ treatments with the concentration of less than $100 \mathrm{mM}$ evokes significant reductions in $L \mathrm{p}_{\mathrm{r}}$ in many plant species is yet to be clarified. Possible significances of the phenomenon would be: (i) Plants shut down $L \mathrm{p}_{\mathrm{r}}$ even upon moderate salinity stress conditions to get ready for more severe stress in advance because such a sequence occurs in nature (that is, moderate stress gradually succeeds to more severe one); and (ii) $L p_{\mathrm{r}}$ reductions could be a sign of conversion of the growth status of plant cells from the rapid growth mode with high water absorption to the protect/tolerant one with less water uptake as a strategy for the survival under salinity stress (Horie et al. 2011b).

Interestingly, no significant change in $L \mathrm{p}_{\mathrm{r}}$ was observed in the plants of japonica rice cultivar Nipponbare under

\section{Salt-stress-induced osmotic change$$
\downarrow
$$$$
\downarrow \text { hours days weeks }
$$ Time after stress \\ Post-translational regulation of aquaporins \\ Transcriptional regulation of aquaporins Structural changes of roots \\ Signal transduction and metabolic changes Accumulation of ions and compatible solutes}

Figure 2 Timeline of regulations and changes in symplastic water-related functions of a plant cell after salt-induced osmotic changes. Blue arrows indicate functions included in the regulation of the water permeability (conductance) of roots, and green arrows indicate functions of the cellular osmotic adjustment. 
salinity stress of $100 \mathrm{mM} \mathrm{NaCl}$ within 24 hrs by the pressure chamber method (Kaneko and Katsuhara, unpublished data). The result suggests that at least Nipponbare rice plants might not be able to promote an immediate repression of the $L \mathrm{p}_{\mathrm{r}}$ in response to the osmotic stress phase. Similar exceptions of no influence of salinity stress on $L \mathrm{p}_{\mathrm{r}}$ have been reported using tobacco (Tyerman et al. 1989) and relatively mature barley plants (Munns and Passioura 1984). Whether the salinity/osmotic-induced $L \mathrm{p}_{\mathrm{r}}$ down-regulation is an essential component of salt tolerant mechanisms in plants and how much influence the existence of the down-regulation has on plant salt tolerance are important questions to be addressed. Moreover, whether the pattern of regulation of $L \mathrm{p}_{\mathrm{r}}$ upon salinity/osmotic stress could be changed depending on the growth stage of the plant species as has been seen in two independent studies using mature barley plants (Munns and Passioura 1984) and barley seedlings (Horie et al. 2011b) is also an interesting question to pursue.

Water transport across cellular membranes is mediated by water channel activity of proteins that belong to the major intrinsic protein (MIP) family called aquaporins (Tyerman et al. 1999; Javot and Maurel 2002; Chaumont et al. 2005; Maurel et al. 2008). Aquaporins are known to be a pore-forming membrane protein, which transport water and low-molecular weight neutral compounds (Tyerman et al. 2002; Maurel et al. 2008). The plasma membrane intrinsic proteins (PIPs) being divided into two phylogenic subgroups PIP1 and PIP2 are one of the four major subfamilies of plant aquaporins and the most abundant aquaporins in the plasma membrane (Maurel et al. 2008). Genetic evidence using tobacco and Arabidopsis plants have indicated that PIP aquaporins mediate water uptake by roots and are a predominant component of the $L \mathrm{p}_{\mathrm{r}}$ (Martre et al. 2002; Siefritz et al. 2002; Javot et al. 2003). Furthermore, the residual $L \mathrm{p}_{\mathrm{r}}$ of salt-stressed Arabidopsis and paprika plants have been shown to be resistant to mercury that is a potent inhibitor of aquaporinmediated water transport, indicating that the downregulated $L \mathrm{p}_{\mathrm{r}}$ component consists of most likely PIP aquaporin activity in these conditions (Carvajal et al. 1999; Martínez-Ballesta et al. 2003). These earlier studies together point that uncovering regulatory mechanisms on aquaporins at the molecular level, including transcriptional and post-translational modifications, are indispensable to understand the physiological significance of $L \mathrm{p}_{\mathrm{r}}$ down-regulation upon salinity/osmotic stress in plants.

Aquaporin genes were found to form a large gene family in several plant species including Arabidopsis and maize (Chaumont et al. 2005). Salinity-induced down-regulation of most aquaporin transcripts has been observed in roots of salt-stressed Arabidopsis and maize plants (Maurel et al. 2008), suggesting that a transcriptional regulation on aquaporin genes contributes to the $L \mathrm{p}_{\mathrm{r}}$ down-regulation under salinity stress. In roots of barley seedlings, the accumulation of ten HvPIP transcripts from $100 \mathrm{mM} \mathrm{NaCl}$ treated plants is similar to those from non-stress condition. However, $200 \mathrm{mM} \mathrm{NaCl}$ stress significantly down-regulated the level of six out of ten HvPIP transcripts (Horie et al. 2011b). The importance of post-translational mechanisms such as protein phosphorylation/dephosphorylation and dynamic changes in subcellular localization via membrane internalization on aquaporin-mediated water transport in roots is being focused (Boursiac et al. 2005; Boursiac et al. 2008; Maurel et al. 2008; Horie et al. 2011b). In Arabidopsis, $100 \mathrm{mM} \mathrm{NaCl}$ treatments induced redistribution of PIPs from the plasma membrane to internal compartments, which could account for the rapid $L \mathrm{p}_{\mathrm{r}}$ down-regulation in $100 \mathrm{mM} \mathrm{NaCl}$-treated Arabidopsis roots (Boursiac et al. 2005). More recent findings further demonstrated that salinity-induced rapid $L \mathrm{p}_{\mathrm{r}}$ down-regulation and redistribution of PIPs to internal compartments are controlled by the salicylic acid-mediated accumulation of reactive oxygen species (ROS), which is stimulated by salinity stress (Boursiac et al. 2008). Together, these findings suggest that mechanisms to regulate PIP aquaporins are one of key mechanisms used by plants to maintain proper $L \mathrm{p}_{\mathrm{p}}$, therefore water homeostasis during salinity/osmotic stress.

In rice plants, 33 aquaporin genes including 11 PIPs were identified (Sakurai et al. 2005). Recent works further showed the expression and localization patterns of PIP proteins, in which several OsPIP1 proteins, OsPIP2;1, and tonoplast-localized TIP proteins, OsTIP1;1 and OsTIP2;2, were found to express in both leaf blades and roots, while OsPIP2;3, OsPIP2;5 and OsTIP2;1 were expressed only in roots (Sakurai et al. 2008; SakuraiIshikawa et al. 2011). A ubiquitous localization of OsPIP2;1 with the abundance in the proximal end (close to the central cylinder) of the endodermis was observed (Figure 3, Sakurai unpublished data), which is similar to the expression pattern of OsPIP2;5 (SakuraiIshikawa et al. 2011). These localizations imply important roles of OsPIP water channels in the water transport of rice plants. Although there is no report regarding post-translational regulations such as phosphorylation/dephosphorylation and endocytotic recycling on PIP aquaporins in rice under salinity stress, salinity/osmotic stress-induced reductions in expression levels of OsPIP and OsTIP mRNAs were detected in rice (Guo et al. 2006; Li et al. 2008). These results suggest that plant aquaporins could be involved in salt tolerant mechanisms by repressing the activity of water channels under salinity stress. In supporting to this hypothesis, over-expression of HvPIP2;1 from barley induced salt hypersensitivity phenotypes in transgenic rice plants (Katsuhara et al. 2003). On the contrary, overexpression of some OsPIPs was found to enhance salt tolerance in Arabidopsis (Guo et al. 2006) and rice 

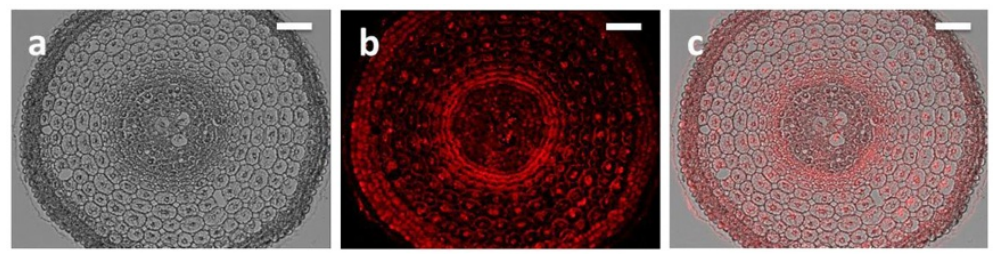

Figure 3 Localizations of OsPIP2;1 in rice root tissues. Rice plants were grown in a hydroponic culture solution and are placed in a growth chamber under a $12 \mathrm{~h}$ dark $(20 \mathrm{C}) / 12 \mathrm{~h}$ light $(25 \mathrm{C})$ photoperiod $\left(370 \mu \mathrm{mol} \mathrm{s} \mathrm{s}^{-1} \mathrm{~m}^{-2}\right.$ for $38 \mathrm{~d}$. Tap root samples were fixed at $3 \mathrm{~h}$ after the onset of the light period. Root sections at around $4 \mathrm{~mm}$ from the root tip were subjected to immunocytochemistry using the anti-OsPIP2;1 antibody. a, Bright field image; $\mathbf{b}$, fluorescent image; $\mathbf{c}$, superimposed image of $\mathbf{a}$ and $\mathbf{b}$. Bars represent $50 \mu \mathrm{m}$ (unpublished, kindly provided by Dr. Junko Sakurai-Ishikawa of NARO Tohoku Agricultural Research Center, Japan).

(Kitagawa, personal communication). These complicated results might be attributed to the different functions of introduced aquaporin genes. Further investigations are needed to reveal the exact physiological roles of aquaporins in salinity/osmotic tolerance mechanisms in planta.

\section{Osmotic adjustments and compatible solutes}

Osmotic adjustments by means of solute accumulations inside the cell are essential to reduce the cellular $\Psi_{\text {osm }}$ against an osmotic gradient between root cells and outside saline solution, which eventually restore the water uptake into roots during salinity stress (Greenway and Munns 1980). Ion accumulations in the cytosol (mainly $\left.\mathrm{K}^{+}\right)$and in the vacuole $\left(\mathrm{Na}^{+}\right.$, especially in salt tolerant cultivars/species) are also found to be important for the osmotic adjustment of plant cells (Gorham et al. 1985). In addition to the accumulation of ions for cellular osmotic adjustment, certain organic compounds are known to accumulate in the cytosol under salinity/osmotic stress conditions. Such compounds are called compatible solutes (Bohnert and Shen 1999). Compatible solutes were initially determined as compounds that are non-toxic even when they are highly accumulated in the cytosol and contribute to decrease the cytoplasmic water potential. In addition to the role in osmotic adjustments, compatible solutes seem to function as a chaperone protecting enzymes and membrane structures, and as a scavenger reducing radical oxygen species under stress conditions including salinity stress (Bohnert and Shen 1999). Rice has two genes encoding the betaine aldehyde dehydrogenase, which catalyzes betaine aldehyde to glycine betaine (GB), a compatible solute. However, rice cannot synthesize GB because of the lack of an upstream enzyme, the choline monooxidase (CMO), which convert a choline to a betaine aldehyde. Introductions of spinach CMO genes or the Arthrobacter pascens choline oxidase into rice plants promoted the synthesis of GB in the transgenic rice plants (Sakamoto et al. 1998; Shirasawa et al. 2006). However, only relatively small amount of GB accumulation and slight enhancement of salt tolerance of transgenic rice plants were observed in some conditions tested, probably because of low activities and/or miss-localization of the introduced enzymes (Shirasawa et al. 2006).

\section{2. $\mathrm{Na}^{+}$over-accumulation and components for the protection from $\mathrm{Na}^{+}$toxicity under salinity stress}

Over-accumulated $\mathrm{Na}^{+}$in the cytoplasm during salinity stress develops toxicity and disturbs essential cellular metabolisms such as protein synthesis, enzyme activity and, in the case of cells that compose the source organ, photosynthesis (Yeo and Flowers 1986; Glenn et al. 1999; Tsugane et al. 1999; Blaha et al. 2000). At the whole plant level, salinity stress leads to $\mathrm{Na}^{+}$overaccumulation in shoots particularly in old leaves, and many reports have suggested that restricting $\mathrm{Na}^{+}$accumulation in shoots under salinity stress is associated with salt tolerance of wheat and barley (Jeschke 1984; Gorham et al. 1990; Munns and James 2003; Garthwaite et al. 2005). Moreover, it has been also reported that $\mathrm{Na}$ ${ }^{+}$accumulation in shoots is relatively well correlated with the survival of rice plants under salinity stress (Yeo et al. 1990). Ionic stress eventually triggers premature senescence of older leaves with stress symptoms such as chlorosis and necrosis (Munns 2002; Munns et al. 2006), which in turn significantly reduces growth and productivity of cereals. Therefore, effective strategies for glycophytes to cope with salinity stress are to keep cytosolic $\mathrm{Na}^{+}$levels low at the cellular level and to keep shoot $\mathrm{Na}^{+}$concentrations low at the whole plant level. In addition to these factors, acquisition and maintenance of $\mathrm{K}^{+}$were found to have a considerable impact on plant salt tolerance (Wu et al. 1996; Zhu et al. 1998). Maintenance of high cytosolic $\mathrm{K}^{+} / \mathrm{Na}^{+}$ratios especially in shoots have been strongly suggested to be crucial for salt tolerance of glycophyte plants (Gorham et al. 1987; Gorham et al. 1990; Blumwald 2000; Ren et al. 2005; Sunarpi et al. 2005; Yamaguchi and Blumwald 2005; Hauser and Horie 2010). In fact, rice cultured cells overexpressing OsKAT1 cDNA, which encodes a Shaker-type $\mathrm{K}^{+}$ 
channel, had enhanced cell growth in the presence of $100 \mathrm{mM}$ and $200 \mathrm{mM} \mathrm{NaCl}$ (Obata et al. 2007). OsKAT1-expressing cells accumulated more $\mathrm{K}^{+}$during salinity stress, which resulted in higher $\mathrm{K}^{+} / \mathrm{Na}^{+}$ratios of OsKAT1-expressing cells than control cells (Obata et al. 2007). Furthermore, a more recent study demonstrated that tobacco cultured cells expressing the rice OsHAK5 transporter that exhibits relatively $\mathrm{Na}^{+}$insensitive $\mathrm{K}^{+}$uptake activity showed an enhancement of growth under salinity stress due to increases in $\mathrm{K}^{+}$accumulations accompanied with decreases in $\mathrm{Na}^{+}$accumulations as proved by the high $\mathrm{K}^{+} / \mathrm{Na}^{+}$ratios of the cells (Horie et al. 2011a). These findings further supported a positive impact of a stable $\mathrm{K}^{+}$acquisition on the cellular salt tolerance.

The underlying mechanisms of $\mathrm{Na}^{+}$entries into plant roots via both symplastic and apoplastic pathways are largely unknown. Based on the proposition by Yeo et al. 1987, at least four different entry mechanisms can be assumed: (i) ion channels/transporters that mediate $\mathrm{Na}^{+}$ selective transport at the plasma membrane of root epidermal/cortical cells, (ii) ion channels/transporters that mediate non-selective cation transport at the plasma membrane of root epidermal/cortical cells, (iii) $\mathrm{Na}^{+}$intrusion into the root symplastic pathway due to a direct leakage through membrane bilayers or an injury in membrane bilayers, and (iv) a direct apoplastic intrusion into the xylem from the outside environment without biological selectivity.

During intrusive $\mathrm{Na}^{+}$entries into the root, plants can exert "selectivity" at three independent biological membranes: the plasma membrane of epidermal/cortical cells, the tonoplast of cells in roots and shoots, and the plasma membrane of the xylem parenchyma cell. In this section, we focus on the physiological functions of several essential components that have been demonstrated to protect plants from $\mathrm{Na}^{+}$toxicity on each biological membrane, with the special attention to the apoplastic $\mathrm{Na}^{+}$flow, which is remarkably considerable in rice plants in the presence of high concentrations of $\mathrm{Na}^{+}$.

\section{A contribution of the apoplastic $\mathrm{Na}^{+}$flow to the shoot $\mathrm{Na}^{+}$accumulation in rice}

A significance of the apoplastic space for the nutrition of higher plants in addition to the symplastic and transcellular solute transports, mediated by plasma membranelocalized channels/transporters and plasmodesmata, has been suggested (Sattelmacher et al. 1998). It has been shown that a significant amount of $\mathrm{Na}^{+}$transported to the shoots during salinity stress is through the apoplastic pathway (the so-called "bypass flow") in the case of the rice plant, which is the most salt sensitive species among the cereals (Yeo et al. 1987; Yadav et al. 1996; Ochiai and Matoh 2002; Anil et al. 2005; Krishnamurthy et al.
2009). Interestingly, in the presence of $100 \mathrm{mM} \mathrm{NaCl}$, the upward $\mathrm{Na}^{+}$transport rate in barley, which is the most salt tolerant cereal, is much lower (only 20\%) when compared to that in rice plants (Munns 1985), suggesting a significant contribution of $\mathrm{Na}^{+}$bypass flow in salinity-induced shoot $\mathrm{Na}^{+}$accumulation in rice plants. In roots, there are morphological components to prevent non-selective apoplastic flow of water and ions into the stele. These morphological components are Casparian bands and suberin lamellae at the root exo- and endodermis (Enstone et al. 2003). Casparian bands and suberin lamellae are deposited in anticlinal walls and on the inner face of the primary cell walls, respectively. Though the mechanism of bypass flow has not been completely understood, bypass flow-mediated $\mathrm{Na}^{+}$overaccumulation in shoots of rice plants is believed to be the outcome of a passive leakage of $\mathrm{Na}^{+}$into the xylem over the morphological barriers. Since the apoplastic space of the leaf is relatively small, the effect of a large quantity of $\mathrm{Na}^{+}$reaching the xylem in saline conditions is significant. In other words, the accumulation of even only a small portion of $\mathrm{Na}^{+}$in the leaf apoplastic space causes large changes in ion concentrations of the space. According to the estimate of Yeo and Flowers (1986), even if $99 \%$ of arriving $\mathrm{Na}^{+}$is successfully sequestered into the expanded rice leaves during salinity stress, the apoplastic $\mathrm{Na}^{+}$concentration could reach $500 \mathrm{mM}$ within 7 days, which would lead to severe cell dehydration and stomatal closure. Furthermore, shoot apoplastic $\mathrm{Na}^{+}$accumulations were found to be negatively correlated with the survival of rice varieties including a highly salt tolerant cultivar Pokkali (Krishnamurthy et al. 2009; Krishnamurthy et al. 2011). Therefore, reducing $\mathrm{Na}^{+}$ transport to the shoots via apoplastic bypass flow is one of the primary subjects to solve in order to enhance salinity tolerance of rice plants.

Despite respectable efforts, the precise entry site for $\mathrm{Na}^{+}$bypass flow remains to be determined. Due to the nature of apoplastic bypass flow, locations in roots with injuries and weak barrier areas were expected to be the potential entry sites. These include lateral root emerging sites and cell walls near the root apices (Yeo et al. 1987) (Figure 4a). In monocot plants, lateral roots initiate to emerge at the pericycle near the phloem, disrupt the endodermal Casparian bands, and eventually break through the barrier in the exodermis as they develop (Ranathunge et al. 2005). It was observed that Casparian bands and suberin lamella in both exo- and endodermis are undetectable at the root tip region (Ranathunge et al. 2003; Schreiber et al. 2005), suggesting an immature barrier status of the rice root tip. Recently, Faiyue et al. (2010) have reported that bypass flow was significantly increased in two independent lateral rootless mutants, lrt 1 and $l r t 2$, and a crown rootless mutant, crt1, using 
a

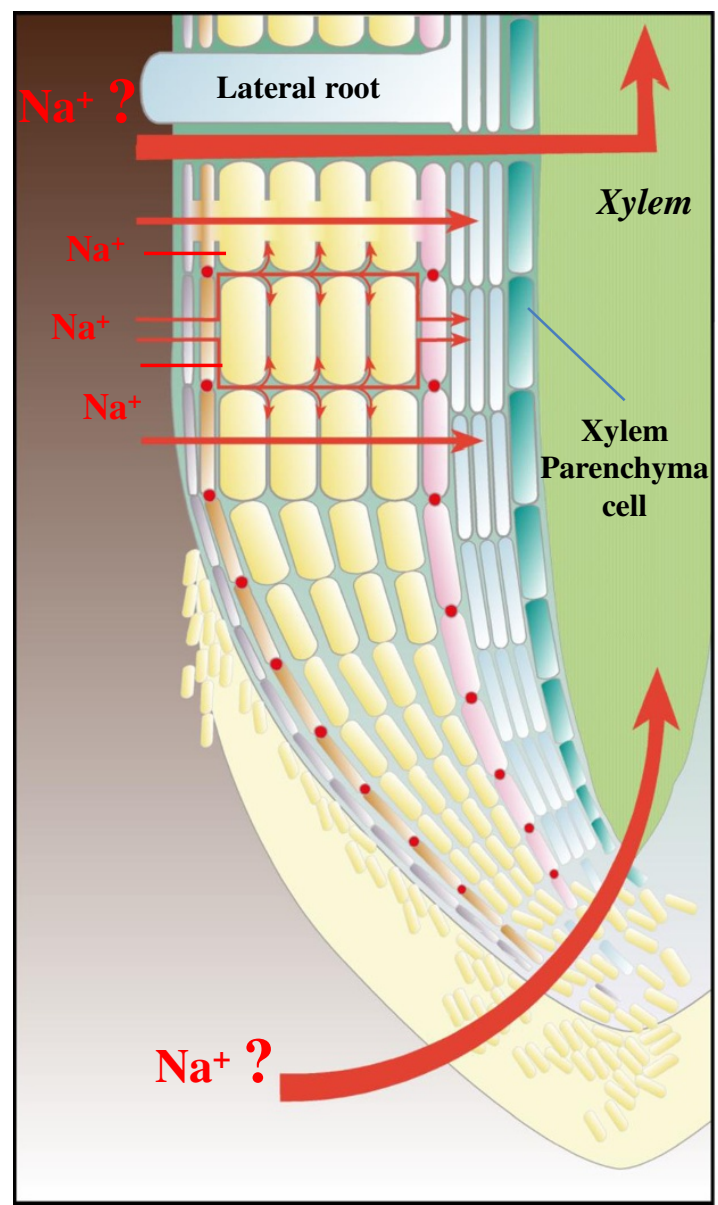

b

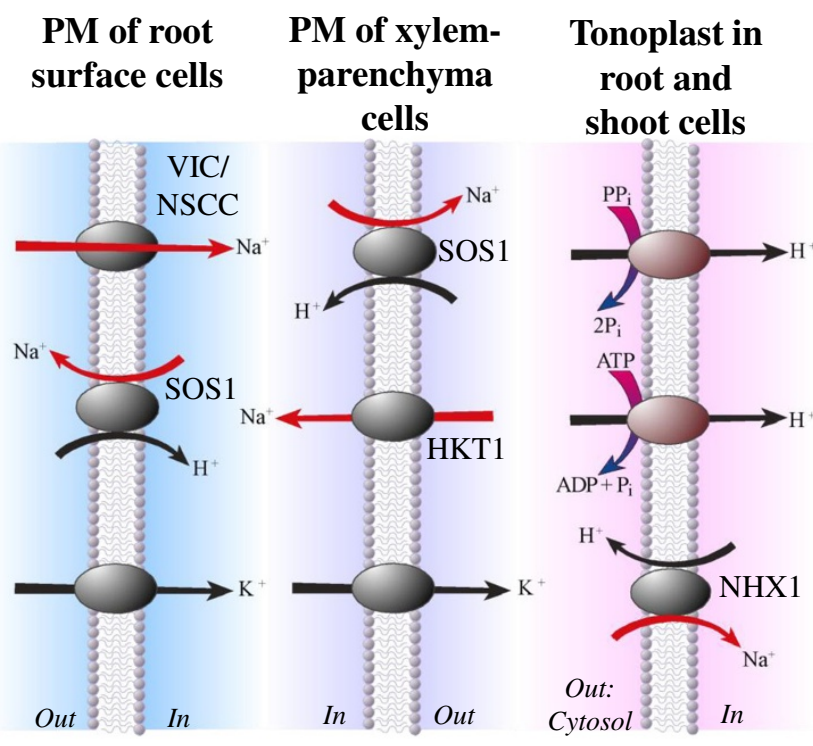

Figure 4 Schematic summaries of $\mathrm{Na}^{+}$influx pathways into saline roots and primary protective mechanisms mediated by $\mathrm{Na}$

${ }^{+}$transporters on important biological membranes. (a) Schematic representations of several entries for $\mathrm{Na}^{+}$influx into roots including cell-tocell and apoplastic pathways. Thick red arrows represent hypothetical $\mathrm{Na}^{+}$entry sites for the apoplastic bypass flow (see text).

(b) Schematic representations of $\mathrm{Na}^{+}$extrusion at the plasma membrane (PM) of the soil-cell interface (left), $\mathrm{Na}^{+}$reabsorption at the PM of the xylem parenchyma cell (XPC: middle), and $\mathrm{Na}^{+}$sequestration into the vacuole at the tonoplast (right). $\mathrm{K}^{+}$transporting proteins in PMs of the soilcell interface and the XPC respectively represent high-affinity $\mathrm{K}^{+}$uptake channels/transporters and $\mathrm{K}^{+}$efflux channels, which could couple with the each $\mathrm{Na}^{+}$transporting mechanism in the PM.

an apoplastic tracer dye, trisodium-8-hydroxy-1,3,6-pyrenetrisulphonic acid (PTS). Based on their results, they concluded that the lateral root emergence does not contribute to be the entry site for the $\mathrm{Na}^{+}$bypass flow (Faiyue et al. 2010). In contrast, however, a more recent study has indicated the leakage of the tracer PTS into the primary root through the breaks created by lateral root emergences in both a salt sensitive cultivar IR20 and Pokkali plants (Krishnamurthy et al. 2011). On the other hand, Ochiai and Matoh (2002) indicated that the tracer dye Fluostain I (also known as Calcoflour White M2R New) was intruded into the xylem with the strong fluorescence around the rice root tip region as well in the presence of $100 \mathrm{mM} \mathrm{NaCl}$, suggesting a significant role of the root apical region in triggering bypass flow. It appears that the issue of the $\mathrm{Na}^{+}$entry site for bypass flow still remains to be an open question. Further studies are needed to elucidate the locations for the $\mathrm{Na}^{+}$entry in the apoplastic flow and the cause of shoot $\mathrm{Na}^{+}$accumulation during salinity stress in rice plants. For more details of the apoplastic water and solute flow in plants, see the section below.

\section{Components for the $\mathrm{Na}^{+}$extrusion from saline roots}

Electrochemical analyses using barley and corn have predicted that active $\mathrm{Na}^{+}$extrusion across the plasma membrane occurs under high salinity (Jeschke 1984). Interestingly, the external $\mathrm{K}^{+}$-dependent net $\mathrm{Na}^{+}$extrusion from $\mathrm{Na}^{+}$-loaded roots $\left(\mathrm{K}^{+}-\mathrm{Na}^{+}\right.$exchange) were found in cereals such as barley, wheat and rye, but not 
in other plant species such as onion, saltbush and buckwheat (Jeschke 1984). This $\mathrm{Na}^{+}$extrusion system, however, seems not to depend on the plasma membrane $\mathrm{Na}^{+} / \mathrm{K}^{+}$-ATPase that mediates the efflux $3 \mathrm{Na}^{+}$and the influx $2 \mathrm{~K}^{+}$, which is ubiquitous in animal cells (Jeschke 1984). Rather, the whole system were suggested to be composed of several independent activities in the plasma membrane, $\mathrm{H}^{+}$-pump ATPases, $\mathrm{H}^{+}-\mathrm{Na}^{+}$antiport and the high-affinity $\mathrm{K}^{+}$uptake (Jeschke 1984), suggesting that the $\mathrm{H}^{+}$-driven $\mathrm{Na}^{+}$exclusion is coupled to the highaffinity $\mathrm{K}^{+}$uptake with the unknown mechanism in cereals (Figure 4b).

Three independent salt overly sensitive SOS mutant loci have been identified in the model plant Arabidopsis thaliana by a genetic screen, which render plants hypersensitive to high concentrations of $\mathrm{Na}^{+}$and $\mathrm{Li}^{+}$but not to the general osmotic stress (Zhu et al. 1998). The initial genetic and physiological analyses revealed growth deficiency of sos mutants under low $\mathrm{K}^{+}$conditions, which leads to an assumption that sos mutant loci are essential components for $\mathrm{K}^{+}$acquisition and signal transduction during salinity stress (Wu et al. 1996; Zhu et al. 1998). In particular, sos1 plants were demonstrated to exhibit deficiency in the high-affinity $\mathrm{K}^{+}$uptake in roots, which suggested a primary role of the SOS1 locus in mediating high-affinity $\mathrm{K}^{+}$ absorption into roots (Wu et al. 1996). Interestingly, however, the SOS1 gene was found to encode the plasma membrane-localized $\mathrm{Na}^{+} / \mathrm{H}^{+}$antiporter, which extrudes $\mathrm{Na}^{+}$out of the cell (Shi et al. 2000). SOS2 and SOS3 genes were found to encode a protein kinase and a $\mathrm{Ca}^{2+}$ binding protein, respectively (Liu and Zhu 1997; 1998; Halfter et al. 2000). They are later grouped into large protein families of calcineurin B-like proteins (CBL) and CBLinteracting protein kinases (CIPK), and therefore SOS2 and SOS3 are also known as CIPK24 and CBL4, respectively (Kolukisaoglu et al. 2004). The working model of essential SOS components were proposed in which the SOS2/SOS3 complex targeted to the plasma membrane via N-myristoylation of SOS3 phosphorylates the SOS1 transporter to exclude $\mathrm{Na}^{+}$(Qiu et al. 2002; Quintero et al. 2002) (Figure 4b). Further physiological analyses together with the SOS1 promoter-GUS analyses revealed that sos1 plants over-accumulate $\mathrm{Na}^{+}$in both xylem sap and shoots, and that the physiological function of the SOS1 transporter is in $\mathrm{Na}^{+}$extrusion particularly in the root apex and also in the long distant $\mathrm{Na}^{+}$transport through the xylem vessel during salinity stress (Shi et al. 2002) (Figure 4b). Note that an electrophysiological study later showed evidence that SOS1-dependent $\mathrm{Na}^{+}$extrusion is in action in more matured epidermal cells as well (Shabala et al. 2005). For more details, see a review (Zhu 2002). Taken together, a significant reduction in the highaffinity $\mathrm{K}^{+}$transport activity due to dysfunctional mutations in the SOS1 gene in Arabidopsis plants implicates a complex interaction between high-affinity $\mathrm{K}^{+}$uptake and $\mathrm{Na}^{+}$extrusion in roots as has been observed in roots of cereals (see above), which remains to be elucidated.

A recent genetic study using barley on $\mathrm{Zn}^{2+}$ accumulation identified a candidate locus named HvNax4, which happened to have a considerable influence on the shoot $\mathrm{Na}^{+}$accumulation (Lonergan et al. 2009). The HvNax4 locus was narrowed down to an approximately $200 \mathrm{~kb}$ region of the long arm of barley chromosome $1 \mathrm{H}$, and the SOS3 gene homolog in barley, $H \nu C B L 4$, in the region was found to co-segregate with the HvNax4 locus (Rivandi et al. 2011). It has been shown that rice plants also maintain large CBL and CIPK protein families similar to Arabidopsis plants (Kolukisaoglu et al. 2004). Furthermore, the cDNAs encoding OsSOS1, OsSOS2 (OsCIPK24) and OsSOS3 (OsCBL4) have been isolated and the functions of those OsSOS proteins were investigated in yeast cells and in Arabidopsis plants (MartínezAtienza et al. 2007). The results demonstrated that all OsSOS proteins could coordinately function with AtSOS proteins in yeast cells and nicely complemented mutations in the corresponding sos mutant of Arabidopsis plants (Martínez-Atienza et al. 2007). Together, these results suggest that the SOS-like salinity tolerance mechanism seems also to be conserved in barley and rice plants. However, important questions remain to be investigated: (i) why the high-affinity $\mathrm{K}^{+}$uptake activity is significantly reduced in sos 1 Arabidopsis mutants? (ii) whether the SOS1-type $\mathrm{Na}^{+} / \mathrm{H}^{+}$exchanger exists and plays a primary function in salt tolerant mechanism in barley as in Arabidopsis?, (iii) if so, whether the SOS-like mechanism is a component constituting the high-affinity $\mathrm{K}^{+}$uptake-coupled $\mathrm{Na}^{+}$extrusion system in barley roots?, and (iv) whether rice roots exhibit activity of the high-affinity $\mathrm{K}^{+}$uptake-coupled $\mathrm{Na}^{+}$extrusion as found in other cereals, in which the OsSOS1-3 protein are involved?

\section{Components for the $\mathrm{Na}^{+}$sequestration into the vacuole}

Under salinity stress, it is crucial for plant cells to maintain the low cytosolic $\mathrm{Na}^{+}$level while keeping the high level of $\mathrm{K}^{+}$, resulting in a high cytosolic $\mathrm{K}^{+} / \mathrm{Na}^{+}$ratio that is preferable for vital cellular metabolisms (Jeschke 1984; Blumwald 2000). It has been shown that the sensitivity of cytosolic enzymes from glycophytes and halophytes to increased salt levels is comparable, suggesting that keeping a high cytosolic $\mathrm{K}^{+} / \mathrm{Na}^{+}$ratio is a basic requirements for plant cells under salinity stress irrespective of the innate difference in the salt sensitivity (Glenn et al. 1999). The sequestration of $\mathrm{Na}^{+}$into vacuoles is an efficient mechanism to reduce the cytosolic $\mathrm{Na}^{+}$concentrations (Yamaguchi and Blumwald 2005). Furthermore, the sequestered $\mathrm{Na}^{+}$ions in the vacuoles can in turn behave as an osmoticum, which 
helps in maintaining the osmotic driving force by promoting water uptake in saline environments.

Biochemical evidence of $\mathrm{Na}^{+} / \mathrm{H}^{+}$antiport activity at the tonoplast membrane was reported in sugar beet (Blumwald and Poole 1985; Blumwald and Poole 1987). The molecular identity of the vacuolar $\mathrm{Na}^{+} / \mathrm{H}^{+}$exchanger of A thaliana plants, AtNHX1, was identified based on the similarity search for the NHX1 gene of Saccharomyces cerevisiae on A. thaliana genome sequence (Apse et al. 1999; Gaxiola et al. 1999) (Figure 4b). Apse et al. (1999) indicated that AtNHX1-overexpression conferred increased salinity tolerance to the transgenic Arabidopsis plants, which were able to grown in the presence of $200 \mathrm{mM} \mathrm{NaCl}$. This result demonstrates that vacuolar $\mathrm{Na}^{+} / \mathrm{H}^{+}$antiport activity is indeed crucial for plant salt tolerance. NHX gene families have been identified in different plant species including cereals such as wheat, barley and rice since AtNHX1 was isolated (Pardo et al. 2006; Rodríguez-Rosales et al. 2009; Yamaguchi et al. 2999). Transgenic plants expressing various NHX1 transporters showed increased salt tolerance (For details, see a review: Yamaguchi and Blumwald 2005), supporting the essentiality of $\mathrm{Na}^{+}$sequestration in salt tolerance (Apse et al. 1999).

In Arabidopsis, six AtNHX genes were identified, whose gene products can be divided into two classes, class I (AtNHX1-4) and class II (AtNHX5 and 6) (Pardo et al. 2006). All class I transporters characterized to date are targeted to the tonoplast (Pardo et al. 2006). The SOS2/CIPK24 protein kinase has been found to involve the regulation of class I NHX-mediated tonoplast $\mathrm{Na}^{+} / \mathrm{H}^{+}$ exchange in Arabidopsis (Qiu et al. 2004). Tonoplast vesicles from sos 2 mutant plants but not from either sos 1 or sos3 mutant plants exhibited a significant reduction in the $\mathrm{Na}^{+} / \mathrm{H}^{+}$exchange activity (Qiu et al. 2004), suggesting that SOS2/CIPK24 also functions in vacuolar $\mathrm{Na}^{+}$sequestration presumably with some $\mathrm{CBL}(\mathrm{s})$ other than SOS3/ CBL4. Unlike vacuolar-localized class I transporters, AtNHX5 and 6 class II transporters were postulated to function in endosomal vesicles (Pardo et al. 2006). A recent study demonstrated that AtNHX5 and AtNHX6 indeed localize at endosomal compartments associated with Golgi and the trans-Golgi network (TGN) and loss of functions of both transporters rendered the atnh $x 5$ atnhx6 double mutant plants more salt sensitive (Bassil et al. 2011). Moreover, the $\operatorname{atnh} x 5$ atnh $x 6$ plants exhibited reduced growth phenotypes even under normal growth condition. These phenotypes include decreases in leaf cell size and number in addition to the impairment of vesicular trafficking to the vacuole (Bassil et al. 2011). These findings suggest that class II NHX-mediated ion homeostasis in endosomal compartments affects protein trafficking from the Golgi/TGN to the vacuole, which could cause increased sensitivity to salinity due to the deficiency in supply of essential components such as AtNHX1 into vacuoles when plants face salinity stress (Bassil et al. 2011). For more details of NHX proteins, see reviews: (Pardo et al. 2006; Rodríguez-Rosales et al. 2009; Yamaguchi et al. 2999.

The vacuolar $\mathrm{Na}^{+} / \mathrm{H}^{+}$exchange activity is driven by the vacuolar proton gradient established by two independent proton pumps, vacuolar $\mathrm{H}^{+}$-ATPase (V-ATPase) and vacuolar $\mathrm{H}^{+}$-translocating pyrophosphatase (VPPase) (Blumwald 1987) (Figure 4b). Constitutive overexpression of a V-PPase of Arabidopsis, AVP1, conferred increased resistance to high concentrations of $\mathrm{Na}^{+}$and drought stress by enhancing cation uptake into vacuoles (Gaxiola et al. 1999; Gaxiola et al. 2001). These findings indicate that enhancement of the driving force for vacuolar $\mathrm{Na}^{+} / \mathrm{H}^{+}$exchange activity is an efficient strategy to increase salinity tolerance in plants, and that vacuolar $\mathrm{Na}^{+}$sequestration is crucial for plant salt tolerance.

Earlier biochemical analyses provided evidence that salt-tolerant Plantago maritima plants maintains a greater salt-induced $\mathrm{Na}^{+} / \mathrm{H}^{+}$antiport activity on the tonoplast than that of salt-sensitive Plantago media plants, suggesting that the innate difference in the ability for the $\mathrm{Na}^{+}$sequestration into vacuoles could be the cause of the difference in salt sensitivity (Staal et al. 1991). Therefore, important questions to be addressed are whether salt tolerant cultivars of glycophytes or halophytes retain better systems such as superior enzyme activity including more preferable activity/ion selectivity of transporting proteins and more efficient regulations on the genes/proteins involved.

\section{Components for the $\mathrm{Na}^{+}$reabsorption from the xylem vessel}

$\mathrm{Na}^{+}$ions that reach the xylem by passing through barrier mechanisms in roots under salinity stress are transported to shoots. In addition to independent barrier components introduced above, plants retain a different protection mechanism at the cell-xylem apoplast interface. It has been shown that $\mathrm{Na}^{+}$reabsorption occurs from the xylem stream by surrounding tissues, and as a result, reduces the net $\mathrm{Na}^{+}$flow into shoots (Läuchli 1984; Lacan and Durand 1996).

The AtHKT1;1 cDNA that encodes a $\mathrm{Na}^{+}$transporter has been isolated from Arabidopsis plants as a homolog of the TaHKT2;1 gene, which is a $\mathrm{Na}^{+} / \mathrm{K}^{+}$co-transporter in wheat (Triticum aestivum) (Schachtman and Schroeder 1994; Rubio et al. 1995; Uozumi et al. 2000). The disruption of the AtHKT1;1 gene was found to render the plants salt hypersensitive with the severe chlorosis in leaves as a result of more $\mathrm{Na}^{+}$in leaves than the wild type plants (Mäser et al. 2002). Several independent laboratories further demonstrated that AtHKT1;1 is an essential component to restrict a $\mathrm{Na}^{+}$accumulation in 
shoots especially in leaves by controlling the net $\mathrm{Na}^{+}$ flow in the long distant $\mathrm{Na}^{+}$transport via the stele (Berthomieu et al. 2003; Sunarpi et al. 2005; Davenport et al. 2007; Horie et al. 2006; Møller et al. 2009). Particularly, Sunarpi et al. (2005) indicated using the antiAtHKT1;1 peptide antibody that AtHKT1;1 localizes at the plasma membrane of xylem parenchyma cells known as a key cell layer controlling the flux of water and solutes in the xylem stream, demonstrating that AtHKT1;1 is a crucial factor in $\mathrm{Na}^{+}$reabsorption from the xylem vessel (Figure 4b). Supporting this, the enhancer trap-mediated targeting expression of AtHKT1;1 in root stellar cells increased an efficiency of the shoot $\mathrm{Na}^{+}$ exclusion and salt tolerance in Arabidopsis plants (Møller et al. 2009). Recently, AtHKT1;1-mediated ion currents were characterized by patch clamp analyses using GFP-labeled root stelar cells from wild-type and athkt1;1 mutant plants and the result provided biophysical evidence that AtHKT1;1 mediates passive $\mathrm{Na}^{+}$channel transport (Xue et al. 2011). Furthermore, independent athkt1;1 mutant alleles caused a reduction in the $\mathrm{K}^{+}$level in xylem vessels and shoots, which were inverted to the increased $\mathrm{Na}^{+}$levels in the same tissues (Sunarpi et al. 2005). Together, these results led to a hypothesis that $\mathrm{Na}^{+}$exclusion mediated by $\mathrm{Na}^{+}$channel activity of AtHKT1;1 from xylem vessels into xylem parenchyma cells indirectly stimulates $\mathrm{K}^{+}$loading to xylem vessels (Sunarpi et al. 2005) (Figure 4b). This hypothesis is consistent with the earlier physiological findings that $\mathrm{Na}^{+}$reabsorption at the xylem occurs in exchange for $\mathrm{K}^{+}$(Läuchli 1984). This mechanism is ideal since plants can manage to not only prevent $\mathrm{Na}^{+}$over-accumulation but also enhance $\mathrm{K}^{+}$accumulation in shoots (Figure $4 \mathrm{~b}$ ), which increases a $\mathrm{K}^{+} / \mathrm{Na}^{+}$ratio in shoots and most importantly in leaves during salinity stress (Horie et al. 2009; Hauser and Horie 2010).

Similar $\mathrm{Na}^{+}$reabsorption mechanisms have been found in cereals such as rice and wheat based on genetic QTL analyses. In rice, the OsHKT1;5 gene has been identified, based on the influence of the shoot $\mathrm{K}^{+}$content (SKC1) locus on the $\mathrm{K}^{+}$accumulation in xylem sap and shoots during salinity stress, as one of the primary genes causing a difference in salt tolerance between a tolerant indica cultivar Nona Bokra and a susceptible japonica cultivar (Ren et al. 2005). The locus was also found to cause a significant increase in the $\mathrm{Na}^{+}$accumulation in xylem vessels and shoots while $\mathrm{K}^{+}$in the same tissues accumulated in the opposite manners (Ren et al. 2005). Given that the product of the OsHKT1;5 gene from the salt tolerant cultivar encoded a $\mathrm{Na}^{+}$transporter that appears to exhibit a higher $\mathrm{Na}^{+}$transport activity than that from sensitive cultivar, the importance of $\mathrm{Na}^{+}$reabsorption from the xylem and the accompanied $\mathrm{K}^{+}$homeostasis for salt tolerance of rice plants were proposed (Ren et al. 2005). The
OsHKT1;5-mediated salt tolerant mechanism in rice was later found to be similar to the AtHKT1;1-mediated $\mathrm{Na}^{+}$ reabsorption mechanism in Arabidopsis (Horie et al. 2009; Hauser and Horie 2010). In wheat, T. aestivum, an essential salt tolerant locus, Kna1, which maintains a high $\mathrm{K}^{+} / \mathrm{Na}^{+}$ratio in shoots during salinity stress, had been identified (Gorham et al. 1987). A more recent QTL analyses using durum wheat revealed that the Nax2 locus that reduces $\mathrm{Na}^{+}$transport from roots to leaf blades by restricting $\mathrm{Na}^{+}$contents of xylem sap is homoeologous to the Kna1 locus, which were eventually suggested to be the HKT1;5 gene in wheat (Munns et al. 2003; James et al. 2006; Byrt et al. 2007). Interestingly, wheat QTL analyses also highlighted the $\operatorname{Nax} 1$ locus, which is another salt tolerant locus that shows very similar features to the Nax2 locus (Munns et al. 2003; James et al. 2006). The Nax1 locus has been suggested to encode the HKT1;4 transporter (Huang et al. 2006), which is a close homolog of AtHKT1;1 and HKT1;5 transporters in rice and wheat, all of which are classified into the class I HKT transporter (Horie et al. 2009; Hauser and Horie 2010). Further details regarding HKT transporters were extensively reviewed elsewhere (Munns and Tester 2008; Horie et al. 2009; Hauser and Horie 2010). Together, these findings strongly suggest that class I HKT transporter-mediated $\mathrm{Na}^{+}$reabsorption at xylem parenchyma cells is a key component for plants to maintain a high $\mathrm{K}^{+} / \mathrm{Na}^{+}$ratio in leaves, which result in salt tolerance of the plants during salinity stress.

In addition to xylem $\mathrm{Na}^{+}$loading, the SOS1 transporter in Arabidopsis plants has been suggested to play a crucial role in $\mathrm{Na}^{+}$retrieval from xylem vessels depending on the degree of salinity stress (Shi et al. 2002). This function overlaps with the role of class I HKT transporters in the stele. However, after considering the thermodynamics of $\mathrm{Na}^{+}$transport with the estimated $\mathrm{pH}$ level of the stele, SOS1-mediated $\mathrm{Na}^{+}$retrieval was deemed to be less likely (Munns and Tester 2008).

Based on the shoot $\mathrm{Na}^{+}$content of barley plants under salinity stress, it has been suggested that salt tolerance is highly associated with the ability to restrict $\mathrm{Na}^{+}$accumulation in shoots (Jeschke 1984). This implies a potential predominant contribution of a similar $\mathrm{Na}^{+}$reabsorption mechanism to salt tolerance of barley as found in Arabidopsis, rice and wheat plants. Interestingly, however, Shabala et al. (2010) recently demonstrated using barley cultivars with differences in their salt tolerance that the extent of salt tolerance of the tolerant cultivars investigated are not necessarily associated with $\mathrm{Na}^{+}$accumulations in xylem sap, but rather related to a significantly higher $\mathrm{K}^{+}$loading property into the xylem stream, which maintain a higher $\mathrm{K}^{+} / \mathrm{Na}^{+}$ratio in xylem sap and thus in shoots. Moreover, salt tolerant cultivars were found to exhibit more efficient $\mathrm{Na}^{+}$sequestration in leaves than 
sensitive cultivars (Shabala et al. 2010), suggesting that higher xylem $\mathrm{K}^{+}$loading and $\mathrm{Na}^{+} / \mathrm{H}^{+}$antiport activity in leaves could be more predominant mechanisms for barley plants to resist salinity stress. The molecular identity of the protein(s) that mediates $\mathrm{K}^{+}$loading to the xylem apoplastic space under salinity stress is yet to be determined. However, $\mathrm{K}^{+}$efflux activity mediated by the $\mathrm{K}^{+}$ outward-rectifying channel (KORC) and/or the nonselective outward-rectifying channel (NORC) (Wegner and Raschke 1994; Wegner and De Boer 1997) could be primary candidates for it (Horie et al. 2009; Hauser and Horie 2010).

In comparison with increasing evidence for the essentiality of the function of some HKT transporters at the cell-xylem apoplastic surface in salt tolerance, regulation mechanisms controlling their activity and expression are largely unknown. A combination of genetic analyses with high-throughput elemental profiling and DNA microarray-based bulk segregant analysis has revealed that the AtHKT1;1 expression was controlled by the tandem repeat region, which is subsequently found to be a dense cluster of small RNAs, that localizes at approximately 4 to $5 \mathrm{~kb}$ upstream of AtHKT1;1 (Rus et al. 2006). A more recent molecular genetic approach demonstrated that a plant hormone cytokinin regulates AtHKT1;1-mediated $\mathrm{Na}^{+}$accumulation in shoots through the transcription factors, ARR1 and ARR12, in Arabidopsis plants (Mason et al. 2010). Further research focusing on the regulation mechanisms of xylem-parenchyma localized HKT transporters will be important to elucidate the contribution of $\mathrm{Na}^{+}$reabsorption to plant salt tolerance.

\section{Toxic $\mathrm{Na}^{+}$influx into roots}

An increase in the $\mathrm{Na}^{+}$concentration of the outer environment triggers passive $\mathrm{Na}^{+}$influx into root cortical cells (Blumwald 2000; Tester and Davenport 2003). Net $\mathrm{Na}^{+}$entry in plant roots is the consequence of passive $\mathrm{Na}^{+}$influx and active $\mathrm{Na}^{+}$efflux. The initial unidirectional $\mathrm{Na}^{+}$influx into saline roots was found to be of a very high rate (Tester and Davenport 2003). Several electrophysiological studies have indicated a primary role of voltage-independent (or weakly voltage-dependent) nonselective cation channels (VIC/NSCC) in such a flux of $\mathrm{Na}^{+}$in saline conditions (see reviews: Amtmann and Sanders 1999; Demidchik et al. 2002; Tester and Davenport 2003). VIC/NSCC currents were found in the cell/ root of several plant species including cereals such as wheat (Tyerman et al. 1997; Davenport and Tester 2000) and barley (Amtmann et al. 1997). Using the fluorescent sodium-sensitive dye, Kader and Lindberg (2005) suggested an involvement of NSCCs in $\mathrm{Na}^{+}$influx into root cells of salt-stressed rice plants. Although the molecular identity of the protein mediating toxic $\mathrm{Na}^{+}$influx is not yet known, cyclic nucleotide-gated channels and ionotropic glutamate receptor-like channels are the primary candidates (Demidchik et al. 2002).

Other potential pathways for the toxic $\mathrm{Na}^{+}$influx into roots are via $\mathrm{K}^{+}$channels/transporters and HKT transporters. A characteristic feature of HKT transporters is the channel-like $\mathrm{Na}^{+}$transport activity in the presence of a large amount of $\mathrm{Na}^{+}$(Gassmann et al. 1996; Xue et al. 2011), which could contribute to $\mathrm{Na}^{+}$overaccumulation in plants. Unlike the case of Arabidopsis plants, HKT transporters were found to form a gene family in cereals including rice (Garciadeblás et al. 2003; Huang et al. 2008). TaHKT2;1-knockdown wheat plants exhibit low $\mathrm{Na}^{+}$influx phenotypes under salt stress and have reduced salt sensitivity (Laurie et al. 2002). $\mathrm{A} \mathrm{Na}^{+}$ transporter OsHKT2;1, one of the seven OsHKT transporters in a japonica rice cultivar Nipponbare, has been demonstrated to mediate $\mathrm{Na}^{+}$influx into roots under $\mathrm{K}^{+}$-starved conditions (Horie et al. 2001; Garciadeblás et al. 2003; Horie et al. 2007; Yao et al. 2010). However, it was also demonstrated that the $\mathrm{Na}^{+}$transport activity of OsHKT2;1 is rapidly down-regulated in intact rice roots even upon a mild salt stress, suggesting that the contribution of OsHKT2; 1 to toxic $\mathrm{Na}^{+}$influx during salinity stress is little (Horie et al. 2007). Given that the OsHKT2;4 transporter exhibited a broad cation transport activity including $\mathrm{Ca}^{2+}$ in Xenopus laevis oocytes, and that immunological detection localized the OsHKT2;4 protein at the plasma membrane of rice root hair cells, a novel physiological role of OsHKT2;4 in $\mathrm{Ca}^{2+}$-linked processes has been proposed (Lan et al. 2010). More recently, OsHKT2;4 was demonstrated to exhibit a strong $\mathrm{K}^{+}$selectivity over divalent cations such as $\mathrm{Ca}^{2+}$ and $\mathrm{Mg}^{2+}$ with an atypical low $\mathrm{Na}^{+}$transport activity compared to other HKT transporters (Horie et al. 2011c), suggesting that the potential contribution of OsHKT2;4 to the toxic $\mathrm{Na}^{+}$influx is unlikely.

Plants retain a large $\mathrm{K}^{+}$transporter family, the KT/ HAK/KUP transporter family (Gierth and Mäser 2007; Ward et al. 2009). It has been demonstrated that high $\mathrm{Na}^{+}$concentrations inhibit $\mathrm{K}^{+}$transport mediated by the HvHAK1 transporter from barley but triggers $\mathrm{Na}^{+}$transport in yeast cells (Santa-María et al. 1997). Moreover, it has been pointed out that even $\mathrm{K}^{+}$channels that are highly selective for $\mathrm{K}^{+}$over $\mathrm{Na}^{+}$could mediate $\mathrm{Na}^{+}$uptake at high salinity (Amtmann and Sanders 1999). $\mathrm{Na}^{+}$ uptake analyses using rice root protoplasts revealed that $\mathrm{K}^{+}$-selective channels as well as NSCCs are involved in the toxic $\mathrm{Na}^{+}$influx (Kader and Lindberg 2005). Together, these results suggest that $\mathrm{K}^{+}$transport systems might also contribute as entry sites for the toxic $\mathrm{Na}^{+}$influx under salinity stress. Further research will be necessary to draw a complete picture of this important process related to plant salt tolerance. 


\section{Pathways of the radial solute movement and apoplastic transport barriers formed in roots}

The root is the only organ that is directly exposed to excess salts under salt stress conditions, and at the same time, the root has important function to take up necessary solutes from the soil. Therefore, it is important how roots avoid the influx of excess salts. Solutes, once taken up by the roots from root surface, move across the root in the radial direction and enter xylem, where they are transported to the shoot. Potentially speaking, there are three pathways for the radial movement of solutes: apoplastic, symplastic and transcellular pathways (Figure 4a). Among these pathways, the transcellular component may be negligible because of the low membrane permeability of most solutes (Steudle and Peterson 1998). A general understanding is that apoplastic transport barriers in roots are present in the endodermis and the exodermis (Perumalla and Peterson 1986). The endodermis of roots of all vascular plants (Clarkson and Robards 1975) and the exodermis of roots of many angiosperms (Perumalla and Peterson 1986; Perumalla et al. 1990) develop the Casparian band that is located in the transverse and the radial walls of cells of these tissues (Figure 5). Suberin is impregnated in the cell wall (Schreiber et al. 1999; Zeier et al. 1999) and the plasma membrane tightly attaches to the cell wall at the site of the Casparian band (Karahara and Shibaoka 1992; 1994). Suberin lamellae are formed in these tissues on the inner surface of the primary cell walls as secondary cell wall modifications after the formation of the Casparian band (Perumalla and Peterson 1986). The function of the Casparian band is to avoid non-selective apoplastic radial movements of solutes into the stele, and the function of suberin lamellae is to block the passage of water and ions through the plasma membrane into the root stele (Steudle and Peterson 1998; Schreiber et al. 1999). Based on the earlier physiological and morphological studies, it is generally considered that the initial uptake of solutes could occur at the epidermis, at the exodermis, or if soil solution flows apoplastically across the root cortex, it would occur at the endodermis (Enstone et al. 2003).

\section{Bypass flow of solutes and the apoplastic pathway in rice roots}

From the general view point mentioned above, it is quite natural to hypothesize that the mechanism of salt exclusion could occur at the exodermis or at the endodermis in the radial direction, and from there, salt is transported radially via a symplastic pathway (Storey and Walker 1998; Munns 2002) because flow of solutes through the apoplast is arrested at the site of the Casparian band and finally solutes are selectively transported through the plasma membrane into the symplast (Figure 5). However, as described in the previous section, studies using apoplastic tracer showed that major pathway of uptaking $\mathrm{Na}^{+}$ions

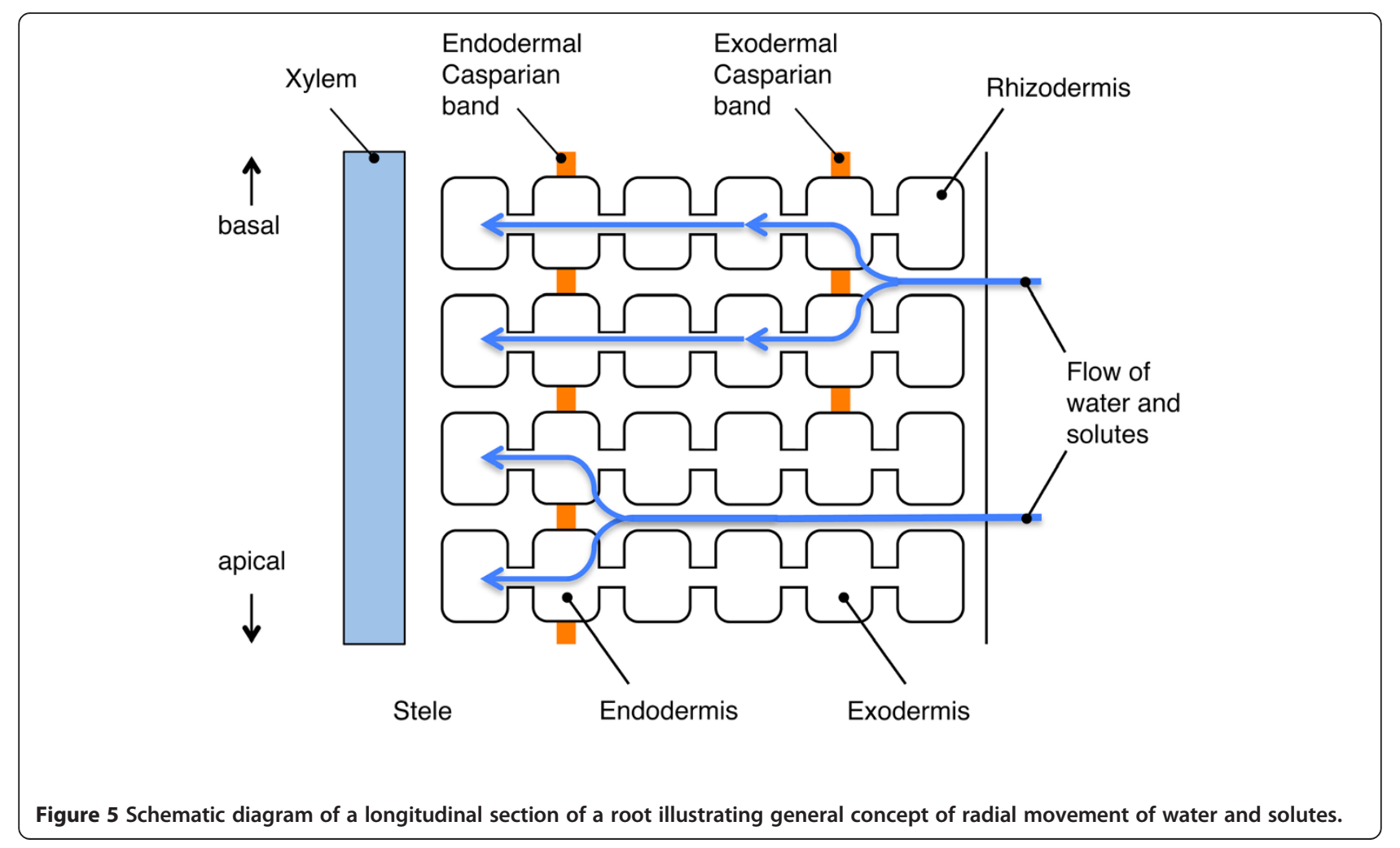


into the stele is apoplastic pathway in the case of rice (Yeo et al. 1987; Yadav et al. 1996; Ochiai and Matoh 2002).

As discussed by Garcia et al. (1997) and also mentioned in the previous section, the uptake of sodium ions by the bypass flow possibly involves direct apoplastic leakage occurring at the root apices (Enstone and Peterson 1992) and the sites of secondary root emergence (Peterson et al. 1981; Ranathunge et al. 2005) (Figure 4a). On the other hand, experiments using pressure probes have indicated a possibility of some passage of water and perhaps also of solutes bypassing protoplasts (Steudle and Frensch 1996). With regard to the outer part of the root (OPR), Ranathunge et al. (2005) performed experiments introducing precipitates of insoluble inorganic salts to block apoplastic pores and suggested existence of predominant apoplastic bypass flow of water as well as high permeability of ions of the OPR, supporting at least a possibility of apoplastic bypass flow of solutes in the OPR. Although it may appear somehow controversial about the mechanism of the bypass flow of solutes, a fascinating model called "composite transport" of both water and solutes is proposed. This model assumes that a switching between the apoplastic and cell-to-cell pathways occurs depending on given circumstances and explains how plants optimize water uptake according to demands from the shoot (Steudle and Frensch 1996; Steudle and Peterson 1998; Miyamoto et al. 2001). The composite transport model may also be applied even to rice roots in which aerenchyma extensively develop (Ranathunge et al. 2005).

A unique point of view accounting for the bypass flow discussed by Munns (2002) is that large gaps created between the plasma membrane and the cell wall may fill with solution and allow an artifactual apoplastic pathway for salts to move radially across the root under salinity stress conditions. However, this view might be unlikely at the sites of the Casparian band because plasma membrane tightly attaches to the cell wall at these sites even under osmotic (or salinity) stress conditions that causes severe plasmolysis (Karahara and Shibaoka 1992).

Silicon alleviates abiotic stresses including salinity stress in rice (Matoh et al. 1986; Ma and Yamaji 2006). This function of silicon may be ascribed, in part, to the partial blockage of the transpirational bypass flow (Ma 2004). In the case of alleviation of cadmium toxicity by silicon in maize, possible involvement of a change in the development of endodermal suberin lamellae is suggested (Vaculik et al. 2009). Such a possibility could also be suggested in the case of alleviation of salinity stress by silicon in rice.

\section{Responses of roots with regard to the apoplastic transport barriers under salinity stress}

To understand the detailed resistance mechanisms to salinity stress as well as of the bypass flow in rice roots, it is undoubtedly necessary to focus on the development and function of the apoplastic transport barriers in roots. Because an issue about the Casparian band development and its potential functions in salt tolerance has been recently reviewed (Chen et al. 2011), here we refer mainly to rice roots. One of the most advantageous features of using rice for plant physiological studies is the availability of many cultivars (varieties) for comparative studies.

Rice roots develop aerenchyma extensively in the cortex (Clark and Harris 1981) and, after its formation, only several cell layers are left intact in the OPR. These cell layers in the OPR are composed of cortical cell layers that appear to be unmodified, sclerenchyma, exodermis, and rhizodermis from the inside to the outside (Clark and Harris 1981) (Figure 6). It is suggested that low overall hydraulic conductivity of rice roots is a result of the existence of apoplastic barriers in the OPR and a strongly developed endodermis (Miyamoto et al. 2001).

Among the structures in the OPR, a unique anatomical feature of rice roots, when compared with other species of cereal plants, is the formation of sclerenchyma of seminal roots and nodal roots (Galamay et al. 1991) (Figure 6). This highly lignified tissue is formed so that it can presumably complement structural weakness caused by the extensive formation of aerenchyma in the cortex of rice roots. This sclerenchyma is composed of single or double cell layers and the number of this cell layers depends on rice varieties and has been considered to have a role in reducing water loss from roots (Feldman 1984). However, no suberin could be detected in sclerenchyma by staining with Sudan Red 7B (Ranathunge et al. 2003), indicating ineffectiveness of this tissue as an apoplastic barrier. Nevertheless, this sclerenchyma might be related to some unique physiological characteristics of rice roots, which is to be revealed in the future.

From the viewpoint of the issue about the bypass flow of water and ions, function of the OPR as the apoplastic barrier was examined using perfusion techniques (Ranathunge et al. 2003; 2005). Ranathunge et al. (2005) perfused the aerenchyma and the ORP with perfusion media containing different salts. When the salt of the outside of the root diffused across the apoplast of the OPR, the two different salts formed a coloured precipitate where they met, indicating a considerable permeability of the exodermal Casparian band to salts (Ranathunge et al. 2005). This phenomenon may be attributed to a part of unique variable features of the exodermis (Hose et al. 2001) and testing a permeability of the endodermis using the same technique would be interesting as mentioned by the same authors (Ranathunge et al. 2005).

Chemical composition of the apoplastic barriers in roots is important for their functions (Schreiber et al. 1999). In fact, the hydraulic conductivity of the apoplastic pathway can be decreased by the deposition of suberin in Casparian 

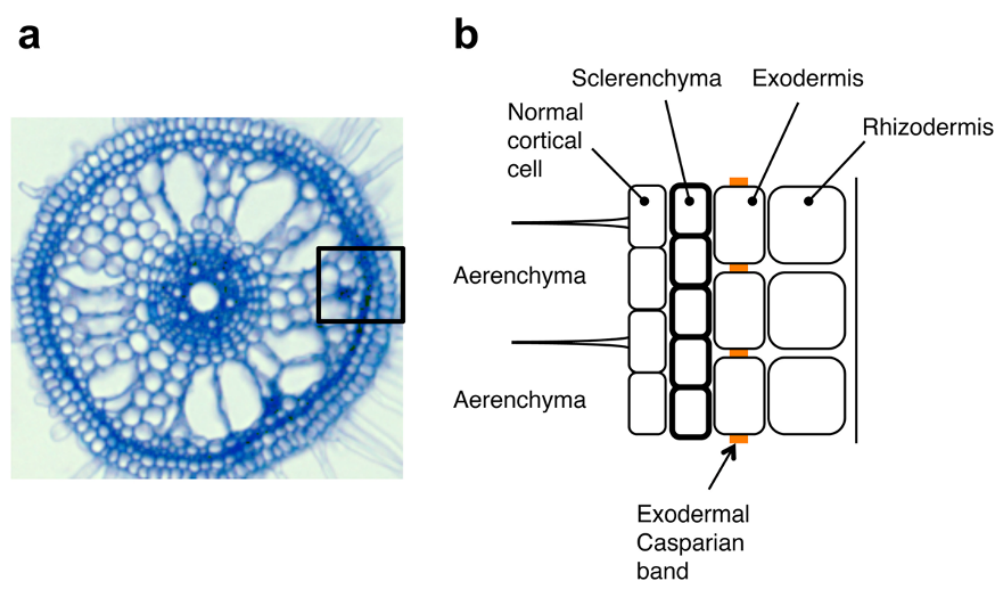

Figure 6 Cellular compositions of the outer part of root (OPR) of a typical rice cultivar. (a) Cross section of a four-day old root of Oryza sativa ssp. japonica cv. Nipponbare. The black rectangular corresponds to the area shown in (b). (b) Schematic diagram of cellular compositions of a cross section of a root OPR.

bands in the cell wall in maize roots (Zimmermann et al. 2000). Suberin is a biopolymer consisting of an aliphatic and an aromatic domain with the aliphatic component being the major contributor to its apoplastic barrier functions (Schreiber et al. 1999). To understand the importance of suberin in apoplastic barriers under salinity stress, comparative analyses of apoplastic barrier formation (i.e., morphology and suberin composition determined by gas chromatography and mass spectrometry) and $\mathrm{Na}^{+}$uptake under salinity stress among different rice cultivars have been performed (Krishnamurthy et al. 2009). They have found that suberization of apoplastic barriers in roots was most extensive in salttolerant cultivar, which also has the least sodium accumulation in the shoots. They also found that salinity stress induced the strengthening of these barriers in both sensitive and tolerant cultivars by increasing the expression of the genes encoding suberin biosynthetic enzymes. Cai et al. (2011) have also performed a similar comparative study using Fourier transform infrared spectroscopy and have found that development and deposition of suberin at the Casparian band in the endoand exodermis were earlier, and the amounts of major chemical components in the OPR, such as aliphatic suberin, lignin and cell wall proteins and carbohydrates, were higher in the most salt-tolerant cultivar examined. These pieces of evidence indicate a correlation between development and suberization of apoplastic barriers and salt tolerance. Furthermore, chemical composition of suberin in rice roots and the roots hydraulic conductivity were analyzed and compared with those in maize roots by Schreiber et al. (2005). They have detected significantly higher amounts of suberin, i.e., 34 times greater in the endodermis and six times greater in the exodermis, in the apoplastic barriers of rice corresponded with a substantially lower root hydraulic conductivity compared with maize. It is no doubt that this higher amount of suberin content in the endodermis indicates the importance of the endodermis as an apoplastic barrier in rice roots. On the other hand, it is also suggested that this is true only for the endodermis because the OPR of rice root is highly porous and permeable to water and that, therefore, more detailed consideration of both the chemical nature and polymer arrangement of suberins in apoplastic barriers is necessary (Schreiber et al. 2005; Ranathunge et al. 2011). A similar opinion was also mentioned in the case of Arabidopsis roots based on a study using suberin mutants (Ranathunge and Schreiber 2011).

Detailed morphological and developmental changes of the Casparian band under salinity stress have been studied in plant species other than rice. Morphometrical analysis performed at the ultrastructural level in maize roots demonstrated that the radial width of the Casparian band on a cross section of a root, a morphological parameter that should be related to the effectiveness of the Casparian band as an apoplastic barrier, increased under salinity stress, suggesting that the function of the band is enhanced under salinity stress (Karahara et al. 2004). With regard to the development of the Casparian band, the distance from the root tip to the lowest position of the exodermal Casparian band decreased in cotton roots under salinity stress (Reinhardt and Rost 1995). From these results, one may conclude salinity can accelerate the formation of Casparian band. It is, however, necessary to interpret these data carefully because the distance from the root tip to the lowest position of the Casparian band 
depends on cell division rate, cell elongation rate as well as the time required for formation of the band in individual cells. This issue was tested in the case of development of the endodermal Casparian band in maize roots under salinity stress and it was demonstrated that the estimated time required for formation of the endodermal Casparian band in an individual cell did not change under salinity stress even when the distance from the root tip to the lowest position of the Casparian band decreased (Karahara et al. 2004). Therefore, a conclusion that Casparian band development is accelerated by salinity stress cannot be drawn exclusively from the observation that the band forms closer to the root tip under the stress. To solve this problem, a unique integrative analysis was proposed to monitor changes in the developmental processes of a particular cell type in the root, i.e. the rates of cell differentiation, production, and elongation (Karahara et al. 2008). As a model case, effects of exogenous ethylene on differentiation, i.e. formation of the endodermal Casparian band, division and elongation of endodermal cells were analyzed in maize primary roots. Effects of environmental stresses, including salinity stress, on the development of barrier structures should be examined or re-examined by this approach. A recent finding of a novel protein family mediating Casparian band formation in the endodermis of Arabidopsis root (Roppolo et al. 2011) has shed a new light on the study of the Casparian band development, which might also be relevant to salt sensitivity of plants.

\section{Conclusion}

Soil salinity is a serious problem in the world agriculture. Owing to efforts of investigators and elevated levels of technologies, our knowledge on the mechanisms of plant salinity tolerance is dramatically expanding these days. However, individual plant species exhibits distinct salt sensitivity due to morphological differences and the difference in the ability of protection components that the plant has evolved to depend on. Therefore, challenges to elucidate the roles/significances of protection mechanisms in plant salt tolerance including morphological barriers at molecular, cellular and whole plant levels in further depth will be crucial to develop high-yielding salt-tolerant cultivars.

\section{Competing interests}

The authors declare that they have no competing interests.

\section{Acknowledgements}

We thank Dr. Junko Sakura-Ishikawa and Dr. Mari Murai-Hatano (NARO Tohoku Agricultural Research Center, Japan) for providing us with the unpublished data. We would also like to thank Dr. Pulla Kaothien-Nakayama for the comments on the manuscript. This work was supported by the grants from the Ministry of Education, Culture, Sports, Science, and Technology, Japan (Grant-in-Aid for Scientific Research no. 23119507 T.H.) and the Program for Promotion of Basic Research Activities for Innovative Biosciences (PROBRAIN), Japan (to M.K.).

\section{Author details}

'Division of Applied Biology, Faculty of Textile Science and Technology, Shinshu University, 3-15-1, Tokida, Ueda, Nagano 386-8567, Japan. ${ }^{2}$ Department of Biology, Graduate School of Science and Engineering, University of Toyama, 3190 Gofuku, Toyama 930-8555, Japan. ${ }^{3}$ Institute of Plant Science and Resources, Okayama University, 20-1, Chuo-2-chome, Kurashiki, Okayama 710-0046, Japan.

\section{Authors' contribution}

$\mathrm{TH}$, writing a part of section 1 and the whole part of section2, and coordinating the contents of this review; IK, writing whole part of the section3; MK, writing the section1. All authors read and approved the final manuscript.

Received: 13 June 2012 Accepted: 22 June 2012

Published: 22 June 2012

\section{References}

Amtmann A, Sanders D (1999) Mechanisms of $\mathrm{Na}^{+}$uptake by plant cells. Adv Bot Res 29:75-112

Amtmann A, Laurie S, Leigh R, Sanders D (1997) Multiple inward channels provide flexibility in $\mathrm{K}^{+} / \mathrm{Na}^{+}$discrimination at the plasma membrane of barley suspension culture cells. J Exp Bot 48:431-440

Anil VS, Krishnamurthy P, Kuruvilla S, Sucharitha K, Thomas G, Mathew MK (2005) Regulation of the uptake and distribution of $\mathrm{Na}^{+}$in shoots of rice (Oryza sativa) variety Pokkali: role of $\mathrm{Ca}^{2+}$ in salt tolerance response. Physiol Plant 124:451-464

Apse MP, Aharon GS, Snedden WA, Blumwald E (1999) Salt tolerance conferred by overexpression of a vacuolar $\mathrm{Na}^{+} / \mathrm{H}^{+}$antiport in Arabidopsis. Science 285:1256-1258

Asch F, Dingkuhn M, Sow A, Audebert A (2005) Drought-induced changes in rooting patterns and assimilate partitioning between root and shoot in upland rice. Field Crop Res 93:223-236

Azaizeh H, Steudle E (1991) Effects of salinity on water transport of excised maize (Zea mays L.) roots. Plant Physiol 97:1136-1145

Bassil E, Ohto MA, Esumi T, Tajima H, Zhu Z, Cagnac O, Belmonte M, Peleg Z, Yamaguchi T, Blumwald E (2011) The Arabidopsis intracellular $\mathrm{Na}^{+} / \mathrm{H}^{+}$ antiporters NHX5 and NHX6 are endosome associated and necessary for plant growth and development. Plant Cell 23:224-239

Berthomieu P, Conejero G, Nublat A, Brackenbury WJ, Lambert C, Savio C, Uozumi N, Oiki S, Yamada K, Cellier F, Gosti F, Simonneau T, Essah PA Tester M, Very AA, Sentenac H, Casse F (2003) Functional analysis of AtHKT1 in Arabidopsis shows that $\mathrm{Na}^{+}$recirculation by the phloem is crucial for salt tolerance. EMBO J 22:2004-2014

Blaha G, StelzI U, Spahn CM, Agrawal RK, Frank J, Nierhaus KH (2000) Preparation of functional ribosomal complexes and effect of buffer conditions on tRNA positions observed by cryoelectron microscopy. Method Enzymol 317:292-309

Blumwald E (1987) Tonoplast vesicles as a tool in the study of ion transport at the plant vacuole. Physiol Plant 69:731-734

Blumwald E (2000) Sodium transport and salt tolerance in plants. Curr Opin Cell Biol 12:431-434

Blumwald E, Poole R (1985) $\mathrm{Na}^{+} / \mathrm{H}^{+}$-antiport in isolated tonoplast vesicles from storage tissue of Beta vulgaris. Plant Physiol 78:163-167

Blumwald E, Poole RJ (1987) Salt tolerance in suspension cultures of sugar beet: induction of $\mathrm{Na}^{+} / \mathrm{H}^{+}$antiport activity at the tonoplast by growth in salt. Plant Physiol 83:884-887

Bohnert HJ, Shen B (1999) Transformation and compatible solutes. Sci Hortic 78:237-260

Boursiac Y, Chen S, Luu DT, Sorieul M, van den Dries N, Maurel C (2005) Early effects of salinity on water transport in Arabidopsis roots. Molecular and cellular features of aquaporin expression. Plant Physiol 139:790-805

Boursiac Y, Boudet J, Postaire O, Luu DT, Tournaire-Roux C, Maurel C (2008) Stimulus-induced downregulation of root water transport involves reactive oxygen species-activated cell signalling and plasma membrane intrinsic protein internalization. Plant J 56:207-218

Byrt CS, Platten JD, Spielmeyer W, James RA, Lagudah ES, Dennis ES, Tester M, Munns R (2007) HKT1:5-like cation transporters linked to $\mathrm{Na}^{+}$exclusion loci in wheat, Nax2 and Kna1. Plant Physiol 143:1918-1928 
Cai X, Chen T, Zhou QY, Xu L, Qu LQ, Hua XJ, Lin JX (2011) Development of Casparian strip in rice cultivars. Plant Signal Behav 6:59-65

Carvajal M, Martinez V, Alcaraz CF (1999) Physiological function of water channels as affected by salinity in roots of paprika pepper. Physiol Plant 105:95-101

Chaumont F, Moshelion M, Daniels MJ (2005) Regulation of plant aquaporin activity. Biol Cell 97:749-764

Chen T, Cai X, Wu X, Karahara I, Schreiber L, Lin J (2011) Casparian strip development and its potential function in salt tolerance. Plant Signal Behav 6:1499-1502

Clark LH, Harris WH (1981) Observations on the root anatomy of rice (Oryza sativa L.). Am J Bot 68:154-161

Clarkson DT, Robards AW (1975) The endodermis, its structural development and physiological role. In: Torrey JG, Clarkson DT (eds) The development and function of roots. Acedemic Press, London, pp 415-436

Davenport RJ, Tester M (2000) A weakly voltage-dependent, nonselective cation channel mediates toxic sodium influx in wheat. Plant Physiol 122:823-834

Davenport RJ, Munoz-Mayor A, Jha D, Essah PA, Rus A, Tester M (2007) The $\mathrm{Na}^{+}$ transporter AtHKT1;1 controls retrieval of $\mathrm{Na}^{+}$from the xylem in Arabidopsis. Plant Cell Environ 30:497-507

Demidchik V, Davenport RJ, Tester M (2002) Nonselective cation channels in plants. Annu Rev Plant Biol 53:67-107

Enstone JE, Peterson CA, Ma FS (2003). Root endodermis and exodermis: structure, function, and responses to the environment. J Plant Growth Regul 21:335-351

Enstone DE, Peterson CA (1992) The apoplastic permeability of root apices. Can J Bot 70:1502-1512

Faiyue B, Vijayalakshmi C, Nawaz S, Nagato Y, Taketa S, Ichii M, Al-Azzawi MJ, Flowers TJ (2010) Studies on sodium bypass flow in lateral rootless mutants Irt1 and Irt2, and crown rootless mutant crll of rice (Oryza sativa L.). Plant Cell Environ 33:687-701

Feldman LJ (1984) Regulation of root development. Annu Rev Plant Physiol 35:223-242

Galamay TO, Kono Y, Yamauchi A, Shimizu M (1991) Comparative root anatomy of seminal and nodal root axes of summer cereals with special reference to the development of hypodermis and cortical sclerenchyma. Jpn J Crop Sci 60:184-190

Garcia A, Rizzo CA, Ud-Din J, Bartos SL, Senadhira D, Flowers TJ, Yeo AR (1997) Sodium and potassium transport to the xylem are inherited independently in rice, and the mechanism of sodium: potassium selectivity differs between rice and wheat. Plant Cell Environ 20:1167-1174

Garciadeblás B, Senn M, Banuelos M, Rodriguez-Navarro A (2003) Sodium transport and HKT transporters: the rice model. Plant J 34:788-801

Garthwaite AJ, von Bothmer R, Colmer TD (2005) Salt tolerance in wild Hordeum species is associated with restricted entry of $\mathrm{Na}^{+}$and $\mathrm{Cl}^{-}$into the shoots. J Exp Bot 56:2365-2378

Gassmann W, Rubio F, Schroeder JI (1996) Alkali cation selectivity of the wheat root high-affinity potassium transporter HKT1. Plant J 10:869-882

Gaxiola RA, Rao R, Sherman A, Grisafi P, Alper SL, Fink GR (1999) The Arabidopsis thaliana proton transporters, AtNhX1 and Avp1, can function in cation detoxification. Proc Natl Acad Sci USA 96:1480-1485

Gaxiola RA, Li J, Undurraga S, Dang LM, Allen GJ, Alper SL, Fink GR (2001) Drought- and salt-tolerant plants result from overexpression of the AVP1 $H^{+}$-pump. Proc Natl Acad Sci USA 98:11444-11449

Gierth M, Mäser P (2007) Potassium transporters in plants-involvement in $\mathrm{K}^{+}$ acquisition, redistribution and homeostasis. FEBS Lett 581:2348-2356

Glenn EP, Brown JJ, Blumwald E (1999) Salt tolerance and crop potential of halophytes. Crit Rev Plant Sci 18:227-255

Gorham J, Wyn Jones RG, McDonnell E (1985) Some mechanisms of salt tolerance in crop plants. Plant Soil 89:15-40

Gorham J, Hardy C, Wyn Jones RG, Joppa LR, Law CN (1987) Chromosomal location of a K/Na discriminating character in the $\mathrm{D}$ genome of wheat. Theor Appl Genet 74:584-588

Gorham J, Wyn Jones RG, Bristol A (1990) Partial characterization of the trait for enhanced $\mathrm{K}^{+}-\mathrm{Na}^{+}$discrimination in the $\mathrm{D}$ genome of wheat. Planta 180:590-597

Greenway H, Munns R (1980) Mechanisms of salt tolerance in nonhalophytes. Ann Rev Plant Phys 31:149-190

Guo L, Wang ZY, Lin H, Cui WE, Chen J, Liu M, Chen ZL, Qu L, Gu H (2006) Expression and functional analysis of the rice plasma membrane intrinsic protein gene family. Cell Res 16:277-286
Hachez C, Zelazny E, Chaumont F (2006) Modulating the expression of aquaporin genes in planta: A key to understand their physiological functions? Biochim Biophys Acta 1758:1142-1156

Halfter U, Ishitani M, Zhu JK (2000) The Arabidopsis SOS2 protein kinase physically interacts with and is activated by the calcium-binding protein SOS3. Proc Natl Acad Sci USA 97:3735-3740

Hauser F, Horie T (2010) A conserved primary salt tolerance mechanism mediated by HKT transporters: a mechanism for sodium exclusion and maintenance of high $\mathrm{K} / \mathrm{Na}$ ratio in leaves during salinity stress. Plant Cell Environ 33:552-565

Horie T, Schroeder II (2004) Sodium transporters in plants. Diverse genes and physiological functions. Plant Physiol 136:2457-2462

Horie T, Yoshida K, Nakayama H, Yamada K, Oiki S, Shinmyo A (2001) Two types of HKT transporters with different properties of $\mathrm{Na}^{+}$and $\mathrm{K}^{+}$transport in Oryza sativa. Plant J 27:129-138

Horie T, Horie R, Chan WY, Leung HY, Schroeder JI (2006) Calcium regulation of sodium hypersensitivities of sos 3 and athkt 1 mutants. Plant Cell Physiol 47:622-633

Horie T, Costa A, Kim TH, Han MJ, Horie R, Leung HY, Miyao A, Hirochika H, An G, Schroeder II (2007) Rice OsHKT2;1 transporter mediates large $\mathrm{Na}^{+}$influx component into $\mathrm{K}^{+}$-starved roots for growth. EMBO J 26:3003-3014

Horie T, Hauser F, Schroeder II (2009) HKT transporter-mediated salinity resistance mechanisms in Arabidopsis and monocot crop plants. Trends Plant Sci 14:660-668

Horie T, Brodsky DE, Costa A, Kaneko T, Lo Schiavo F, Katsuhara M, Schroeder JI (2011a) $\mathrm{K}^{+}$transport by the OsHKT2;4 transporter from rice with atypical $\mathrm{Na}^{+}$ transport properties and competition in permeation of $\mathrm{K}^{+}$over $\mathrm{Mg}^{2+}$ and $\mathrm{Ca}^{2+}$ ions. Plant Physiol 156:1493-1507

Horie T, Kaneko T, Sugimoto G, Sasano S, Panda SK, Shibasaka M, Katsuhara M (2011b) Mechanisms of water transport mediated by PIP aquaporins and their regulation via phosphorylation events under salinity stress in barley roots. Plant Cell Physiol 52:663-675

Horie T, Sugawara M, Okada T, Taira K, Kaothien-Nakayama P, Katsuhara M, Shinmyo A, Nakayama H (2011c) Rice sodium-insensitive potassium transporter, OsHAK5, confers increased salt tolerance in tobacco BY2 cells. J Biosci Bioeng 111:346-356

Hose E, Clarkson DT, Steudle E, Schreiber L, Hartung W (2001) The exodermis: a variable apoplastic barrier. J Exp Bot 52:2245-2264

Huang S, Spielmeyer W, Lagudah ES, James RA, Platten JD, Dennis ES, Munns R (2006) A sodium transporter (HKT7) is a candidate for Nax1, a gene for salt tolerance in durum wheat. Plant Physiol 142:1718-1727

Huang S, Spielmeyer W, Lagudah ES, Munns R (2008) Comparative mapping of HKT genes in wheat, barley, and rice, key determinants of $\mathrm{Na}^{+}$transport, and salt tolerance. J Exp Bot 59:927-937

IRRI (2011) Stress and disease tolerance: 1. Breeding for salt tolerance in rice. http://www.knowledgebank.irri.org/ricebreedingcourse/bodydefault. htm\#breeding_for_salt_tolerance.htm. 2006; Accessed 12 October

James RA, Davenport RJ, Munns R (2006) Physiological characterization of two genes for $\mathrm{Na}^{+}$exclusion in durum wheat, $\mathrm{Nax} 1$ and Nax2. Plant Physiol 142:1537-1547

Javot H, Maurel C (2002) The role of aquaporins in root water uptake. Ann Bot 90:301-313

Javot H, Lauvergeat V, Santoni V, Martin-Laurent F, Guclu J, Vinh J, Heyes J, Franck KI, Schaffner AR, Bouchez D, Maurel C (2003) Role of a single aquaporin isoform in root water uptake. Plant Cell 15:509-522

Jeschke WD (1984) $\mathrm{K}^{+}-\mathrm{Na}^{+}$Exchange at Cellular Mmbranes, Intracellular Compartmentation of Cations, and Salt Tolerance. Sanity Tolerance in Plant. Strategies for Crop Improvement. Wiley-Interscience Publication, New York, pp 33-76

Jia W, Wang Y, Zhang S, Zhang J (2002) Salt-stress-induced ABA accumulation is more sensitively triggered in roots than in shoots. $J$ Exp Bot 53:2201-2206

Kader MA, Lindberg S (2005) Uptake of sodium in protoplasts of salt-sensitive and salttolerant cultivars of rice, Oryza sativa L. determined by the fluorescent dye SBFI. J Exp Bot 56:3149-3158

Karahara I, Shibaoka H (1992) Isolation of Casparian strips from pea roots. Plant Cell Physiol 33:555-561

Karahara I, Shibaoka H (1994) The Casparian strip in pea epicotyls: effects of light on its development. Planta 192:269-275

Karahara I, Ikeda A, Kondo T, Uetake Y (2004) Development of the Casparian strip in primary roots of maize under salt stress. Planta 219:41-47 
Karahara I, Matsuda K, Honma Y (2008) Effects of ethylene on the production, elongation, and differentiation of endodermal cells in maize primary root: An integrative analysis of the developmental process of a particular cell type. Plant Root 2:29-37

Katsuhara M, Koshio K, Shibasaka M, Hayashi Y, Hayakawa T, Kasamo K (2003) Over-expression of a barley aquaporin increased the shoot/root ratio and raised salt sensitivity in transgenic rice plants. Plant Cell Physiol 44:1378-1383

Kjellbom P, Larsson C, Johansson II, Karlsson M, Johanson U (1999) Aquaporins and water homeostasis in plants. Trends Plant Sci 4:308-314

Kolukisaoglu U, Weinl S, Blazevic D, Batistic O, Kudla J (2004) Calcium sensors and their interacting protein kinases: genomics of the Arabidopsis and rice CBLCIPK signaling networks. Plant Physiol 134:43-58

Kramer PJ, Boyer JS (1985) Cell Water Relations. Water Relations of Plants and Soils. Academic, San Diego, pp 42-83

Krishnamurthy P, Ranathunge K, Franke R, Prakash HS, Schreiber L, Mathew MK (2009) The role of root apoplastic transport barriers in salt tolerance of rice (Oryza sativa L.). Planta 230:119-134

Krishnamurthy P, Ranathunge K, Nayak S, Schreiber L, Mathew MK (2011) Root apoplastic barriers block $\mathrm{Na}^{+}$transport to shoots in rice (Oryza sativa L.). J Exp Bot 62:4215-4228

Lacan D, Durand M (1996) $\mathrm{Na}^{+}-\mathrm{K}^{+}$Exchange at the Xylem/Symplast Boundary (Its Significance in the Salt Sensitivity of Soybean). Plant Physiol 110:705-711

Lan WZ, Wang W, Wang SM, Li LG, Buchanan BB, Lin HX, Gao JP, Luan S (2010) A rice high-affinity potassium transporter HKT conceals a calcium-permeable cation channel. Proc Natl Acad Sci USA 107:7089-7094

Läuchli A (1984) Salt exclusion: an adaptation of legumes for crops and pastures under saline conditions. Salinity Tolerance in Plants. Strategies for Crop Improvement. Wiley-Interscience Publication, New York, pp 171-187

Laurie S, Feeney KA, Maathuis FJ, Heard PJ, Brown SJ, Leigh RA (2002) A role for HKT1 in sodium uptake by wheat roots. Plant J 32:139-149

Li GW, Peng YH, Yu X, Zhang MH, Cai WM, Sun WN, Su WA (2008) Transport functions and expression analysis of vacuolar membrane aquaporins in response to various stresses in rice. J Plant Physiol 165:1879-1888

Liu J, Zhu JK (1997) An Arabidopsis mutant that requires increased calcium for potassium nutrition and salt tolerance. Proc Natl Acad Sci USA 94:14960-14964

Liu J, Zhu JK (1998) A calcium sensor homolog required for plant salt tolerance. Science 280:1943-1945

Lonergan PF, Pallotta MA, Lorimer M, Paull JG, Barker SJ, Graham RD (2009) Multiple genetic loci for zinc uptake and distribution in barley (Hordeum vulgare). New Phytol 184:168-179

Ma JF (2004) Role of silicon in enhancing the resistance of plants to biotic and abiotic stresses. Soil Sci Plant Nutr 50:11-18

Ma JF, Yamaji N (2006) Silicon uptake and accumulation in higher plants. Trends Plant Sci 11:392-397

Martínez-Atienza J, Jiang X, Garciadeblas B, Mendoza I, Zhu JK, Pardo JM, Quintero FJ (2007) Conservation of the salt overly sensitive pathway in rice. Plant Physiol 143:1001-1012

Martínez-Ballesta MC, Martinez V, Carvajal M (2000) Regulation of water channel activity in whole roots and in protoplasts from roots of melon plants grown under saline conditions. Aust J Plant Physiol 27:685-691

Martínez-Ballesta MC, Aparicio F, Pallas V, Martinez V, Carvajal M (2003) Influence of saline stress on root hydraulic conductance and PIP expression in Arabidopsis. J Plant Physiol 160:689-697

Martre P, Morillon R, Barrieu F, North GB, Nobel PS, Chrispeels MJ (2002) Plasma membrane aquaporins play a significant role during recovery from water deficit. Plant Physiol 130:2101-2110

Mäser P, Eckelman B, Vaidyanathan R, Horie T, Fairbairn DJ, Kubo M, Yamagami M, Yamaguchi M, Nishimura M, Uozumi N, Robertson W, Sussman MR, Schroeder II (2002) Altered shoot/root $\mathrm{Na}^{+}$distribution and bifurcating salt sensitivity in Arabidopsis by genetic disruption of the $\mathrm{Na}^{+}$transporter AtHKT1. FEBS Lett 531:157-161

Mason MG, Jha D, Salt DE, Tester M, Hill K, Kieber JJ, Schaller GE (2010) Type-B response regulators ARR1 and ARR12 regulate expression of AtHKT1;1 and accumulation of sodium in Arabidopsis shoots. Plant J 64:753-763

Matoh T, Kairusmee P, Takahashi E (1986) Salt-induced damage to rice plants and alleviation effect of silicate. Soil Sci Plant Nutr 32:295-304
Maurel C, Verdoucq L, Luu DT, Santoni V (2008) Plant aquaporins: membrane channels with multiple integrated functions. Annu Rev Plant Biol 59:595-624

Miyamoto N, Steudle E, Hirasawa T, Lafitte R (2001) Hydraulic conductivity of rice roots. J Exp Bot 52:1835

Møller IS, Gilliham M, Jha D, Mayo GM, Roy SJ, Coates JC, Haseloff J, Tester M (2009) Shoot $\mathrm{Na}^{+}$exclusion and increased salinity tolerance engineered by cell type-specific alteration of $\mathrm{Na}^{+}$transport in Arabidopsis. Plant Cell 21:2163-2178

Munns $\mathrm{R}(1985) \mathrm{Na}^{+}, \mathrm{K}^{+}$and $\mathrm{Cl}^{-}$in xylem sap flowing toi shoots of $\mathrm{NaCl}$-treated barley. J Exp Bot 36:1032-1042

Munns R (2002) Comparative physiology of salt and water stress. Plant Cell Environ 25:239-250

Munns R, James RA (2003) Screening methods for salinity tolerance: a case study with tetraploid wheat. Plant Soil 253:201-218

Munns R, Passioura JB (1984) Hydraulic resistance of plants. III. Effects of $\mathrm{NaCl}$ in barley and lupin. Aust J Plant Physiol 11:351-359

Munns R, Tester M (2008) Mechanisms of salinity tolerance. Annu Rev Plant Biol 59:651-681

Munns R, Rebetzke GJ, Husain S, James RA, Hare RA (2003) Genetic control of sodium exclusion in durum wheat. Aust J Agr Res 54:627-635

Munns R, James RA, Läuchli A (2006) Approaches to increasing the salt tolerance of wheat and other cereals. J Exp Bot 57:1025-1043

Obata T, Kitamoto HK, Nakamura A, Fukuda A, Tanaka Y (2007) Rice shaker potassium channel OsKAT1 confers tolerance to salinity stress on yeast and rice cells. Plant Physiol 144:1978-1985

Ochiai K, Matoh T (2002) Characterization of the $\mathrm{Na}^{+}$delivery from roots to shoots in rice under saline stress: excessive salt enhances apoplastic transport in rice plants. Soil Sci Plant Nutr 48:371-378

Pardo JM, Cubero B, Leidi EO, Quintero FJ (2006) Alkali cation exchangers: roles in cellular homeostasis and stress tolerance. J Exp Bot 57:1181-1199

Perumalla CJ, Peterson CA (1986) Deposition of Casparian bands and suberin lamellae in the exodermis and endodermis of young corn and onion roots. Can J Bot 64:1873-1878

Perumalla CJ, Peterson CA, Enstone DE (1990) A survey of angiosperm species to detect hypodermal Gasparian bands. I. Roots with a uniseriate hypodermis and epidermis. Bot J Linn Soc 103:93-112

Peterson CA, Emanuel ME, Humphreys GB (1981) Pathway of movement of apoplastic fluorescent dye tracers through the endodermis at the site of secondary root formation in corn (Zea mays) and broad bean (Vicia faba). Can J Bot 59:618-625

Peyrano G, Taleisnik E, Quiroga M, de Forchetti SM, Tigier H (1997) Salinity effects on hydraulic conductance, lignin content and peroxydase activity in tomato roots. Plant Physiol Biochem 35:387-393

Qiu QS, Guo Y, Dietrich MA, Schumaker KS, Zhu JK (2002) Regulation of SOS1, a plasma membrane $\mathrm{Na}^{+} / \mathrm{H}^{+}$exchanger in Arabidopsis thaliana, by SOS2 and SOS3. Proc Natl Acad Sci USA 99:8436-8441

Qiu QS, Guo Y, Quintero FJ, Pardo JM, Schumaker KS, Zhu JK (2004) Regulation of vacuolar $\mathrm{Na}^{+} / \mathrm{H}^{+}$exchange in Arabidopsis thaliana by the salt-overly-sensitive (SOS) pathway. J Biol Chem 279:207-215

Quintero FJ, Ohta M, Shi H, Zhu JK, Pardo JM (2002) Reconstitution in yeast of the Arabidopsis SOS signaling pathway for $\mathrm{Na}^{+}$homeostasis. Proc Natl Acad Sci USA 99:9061-9066

Ranathunge K, Schreiber L (2011) Water and solute permeabilities of Arabidopsis roots in relation to the amount and composition of aliphatic suberin. J Exp Bot 62:1961-1974

Ranathunge K, Steudle E, Lafitte R (2003) Control of water uptake by rice (Oryza sativa L.): role of the outer part of the root. Planta 217:193-205

Ranathunge K, Steudle E, Lafitte R (2005) Blockage of apoplastic bypass-flow of water in rice roots by insoluble salt precipitates analogous to a Pfeffer cell. Plant Cell Environ 28:121-133

Ranathunge K, Schreiber L, Franke R (2011) Suberin research in the genomics era-new interest for an old polymer. Plant Sci 180:399-413

Reinhardt DH, Rost TL (1995) Salinity accelerates endodermal development and induces an exodermis in cotton seedling roots. Environ Exp Bot 35:563-574

Ren ZH, Gao JP, Li LG, Cai XL, Huang W, Chao DY, Zhu MZ, Wang ZY, Luan S, Lin HX (2005) A rice quantitative trait locus for salt tolerance encodes a sodium transporter. Nat Genet 37:1141-1146

Rivandi J, Miyazaki J, Hrmova M, Pallotta M, Tester M, Collins NC (2011) A SOS3 homologue maps to HvNax4, a barley locus controlling an environmentally sensitive $\mathrm{Na}^{+}$exclusion trait. J Exp Bot 62:1201-1216 
Rodríguez-Rosales MP, Galvez FJ, Huertas R, Aranda MN, Baghour M, Cagnac O, Venema K (2009) Plant NHX cation/proton antiporters. Plant Signal Behav 4:265-276

Roppolo D, De Rybel B, Tendon VD, Pfister A, Alassimone J, Vermeer JE, Yamazaki M, Stierhof YD, Beeckman T, Geldner N (2011) A novel protein family mediates Casparian strip formation in the endodermis. Nature 473:380-383

Rubio F, Gassmann W, Schroeder JI (1995) Sodium-driven potassium uptake by the plant potassium transporter HKT1 and mutations conferring salt tolerance. Science 270:1660-1663

Rus A, Baxter I, Muthukumar B, Gustin J, Lahner B, Yakubova E, Salt DE (2006) Natural variants of AtHKT1 enhance $\mathrm{Na}^{+}$accumulation in two wild populations of Arabidopsis. PLoS Genet 2:e210

Sakamoto A, Murata A, Murata N (1998) Metabolic engineering of rice leading to biosynthesis of glycinebetaine and tolerance to salt and cold. Plant Mol Biol 38:1011-1019

Sakurai J, Ishikawa F, Yamaguchi T, Uemura M, Maeshima M (2005) Identification of 33 rice aquaporin genes and analysis of their expression and function. Plant Cell Physiol 46:1568-1577

Sakurai J, Ahamed A, Murai M, Maeshima M, Uemura M (2008) Tissue and cellspecific localization of rice aquaporins and their water transport activities. Plant Cell Physiol 49:30-39

Sakurai-Ishikawa J, Murai-Hatano M, Hayashi H, Ahamed A, Fukushi K, Matsumoto T, Kitagawa Y (2011) Transpiration from shoots triggers diurnal changes in root aquaporin expression. Plant Cell Environ 34:1150-1163

Santa-María GE, Rubio F, Dubcovsky J, Rodríguez-Navarro A (1997) The HAK1 gene of barley is a member of a large gene family and encodes a highaffinity potassium transporter. Plant Cell 9:2281-2289

Sattelmacher B, Mühling KH, Pennewiß K (1998) The apoplast-its significance for the nutrition of higher plants. J Plant Nutr Soil Sci 161:485-498

Schachtman DP, Schroeder JI (1994) Structure and transport mechanism of a high-affinity potassium uptake transporter from higher plants. Nature 370:655-658

Schreiber L, Hartmann K, Skrabs M, Zeier Jr (1999) Apoplastic barriers in roots: chemical composition of endodermal and hypodermal cell walls. J Exp Bot 50:1267-1280

Schreiber L, Franke R, Hartmann KD, Ranathunge K, Steudle E (2005) The chemical composition of suberin in apoplastic barriers affects radial hydraulic conductivity differently in the roots of rice (Oryza sativa L. Cv. IR64) and corn (Zea mays L. cv. Helix). J Exp Bot 56:1427-1436

Shabala L, Cuin TA, Newman IA, Shabala S (2005) Salinity-induced ion flux patterns from the excised roots of Arabidopsis sos mutants. Planta 222:1041-1050

Shabala S, Cuin TA, Pang J, Percey W, Chen Z, Conn S, Eing C, Wegner LH (2010) Xylem ionic relations and salinity tolerance in barley. Plant J 61:839-853

Shi H, Ishitani M, Kim C, Zhu JK (2000) The Arabidopsis thaliana salt tolerance gene SOS1 encodes a putative $\mathrm{Na}^{+} / \mathrm{K}^{+}$antiporter. Proc Natl Acad Sci USA 97:6896-6901

Shi H, Quintero FJ, Prado JM, Zhu JK (2002) The putative plasma membrane $\mathrm{Na}^{+}-\mathrm{H}^{+}$antiporter SOS1 controls long-distance $\mathrm{Na}^{+}$transport in plants. Plant Cell 14:465-477

Shirasawa K, Takabe T, Kishitani S (2006) Accumulation of glycinebetaine in rice plants that overexpress choline monooxygenase from spinach and evaluation of their tolerance to abiotic stress. Ann Bot 98:565-571

Siefritz F, Tyree MT, Lovisolo C, Schubert A, Kaldenhoff R (2002) PIP1 plasma membrane aquaporins in tobacco: from cellular effects to function in plants. Plant Cell 14:869-876

Staal M, Maathuis FJM, Elzenga JTM, Overbeek JHM, Prins HBA (1991) $\mathrm{Na}^{+} / \mathrm{H}^{+}$ Antiport Activity in Tonoplast Vesicles from Roots of the Salt-Tolerant Plantago maritima and the Salt-Sensitive Plantago media. Physiol Plant 82:179-184

Steudle E, Frensch J (1996) Water transport in plants: role of the apoplast. Plant Soil 187:67-79

Steudle E, Peterson CA (1998) How does water get through roots? J Exp Bot 49:775-788

Storey R, Walker RR (1998) Citrus and salinity. Sci Hortic 78:39-81

Sunarpi, Horie T, Motoda J, Kubo M, Yang H, Yoda K, Horie R, Chan WY, Leung HY, Hattori K, Konomi M, Osumi M, Yamagami M, Schroeder II, Uozumi N (2005) Enhanced salt tolerance mediated by AtHKT1 transporter-induced $\mathrm{Na}^{+}$unloading from xylem vessels to xylem parenchyma cells. Plant J 44:928-938

Tester M, Davenport R (2003) $\mathrm{Na}^{+}$tolerance and $\mathrm{Na}^{+}$transport in higher plants. Ann Bot 91:503-527

Tsugane K, Kobayashi K, Niwa Y, Ohba Y, Wada K (1999) A recessive Arabidopsis mutant that grows photoautotrophically under salt stress shows enhanced active oxygen detoxification. Plant Cell 11:1195-1206
Tyerman SD, Oats P, Gibbs J, Dracup M, Greenway H (1989) Turgor volume regulation and cellular water relations of Nicotiana tabacum roots grown in high salinities. Aust J Plant Physiol 16:517-531

Tyerman S, Skerrett M, Garrill A, Findlay G, Leigh R (1997) Pathways for the permeation of $\mathrm{Na}^{+}$and $\mathrm{Cl}^{-}$into protoplasts derived from the cortex of wheat roots. J Exp Bot 48:459-480

Tyerman SD, Bohnert HJ, Maurel C, Steudle E, Smith JA (1999) Plant aquaporins: their molecular biology, biophysics and significance for plant water relations. J Exp Bot 50:1055-1071

Tyerman SD, Niemietz CM, Bramley H (2002) Plant aquaporins: multifunctional water and solute channels with expanding roles. Plant Cell Environ 25:173-194

Uozumi N, Kim EJ, Rubio F, Yamaguchi T, Muto S, Tsubota A, Bakker EP, Nakamura T, Schroeder JI (2000) The Arabidopsis HKT1 gene homologue mediates inward $\mathrm{Na}^{+}$currents in Xenopus oocytes and $\mathrm{Na}^{+}$uptake in Saccharomyces cerevisiae. Plant Physiol 121:1249-1259

Vaculik M, Lux A, Luxova M, Tanimoto E, Lichtscheidl I (2009) Silicon mitigates cadmium inhibitory effects in young maize plants. Environ Exp Bot 67:52-58

Ward JM, Mäser P, Schroeder JI (2009) Plant ion channels: gene families, physiology, and functional genomics analyses. Annu Review Physiol 71:59-82

Wegner LH, De Boer AH (1997) Properties of two outward-rectifying channels in root xylem parenchyma cells suggest a role in $\mathrm{K}^{+}$homeostasis and longdistance signaling. Plant Physiol 115:1707-1719

Wegner LH, Raschke K (1994) Ion channels in the xylem parenchyma of barley roots. Plant Physiol 105:799-813

Wu SJ, Ding L, Zhu JK (1996) sos 1, a genetic locus essential for salt tolerance and potassium acquisition. Plant Cell 8:617-627

Xue S, Yao X, Luo W, Jha D, Tester M, Horie T, Schroeder Jl (2011) AtHKT1;1 Mediates Nernstian Sodium Channel Transport Properties in Arabidopsis Root Stelar Cells. PLoS One 6:e24725

Yadav R, Flowers TJ, Yeo AR (1996) The involvement of the transpirational bypass flow in sodium uptake by high- and low sodium-transporting lines of rice developed through intravarietal selection. Plant Cell Environ 19:329-336

Yamaguchi T, Blumwald E (2005) Developing salt-tolerant crop plants: challenges and opportunities. Trends Plant Sci 10:615-620

Yamaguchi T, Uozumi N, Horie T (2999) Potassium and sodium transporters: improving salinity tolerance in plants. Improving Crop Resistance to Abiotic Stress. Wiley-VCH Verlag GmbH \& Co, Germany, in press

Yao X, Horie T, Xue S, Leung HY, Katsuhara M, Brodsky DE, Wu Y, Schroeder I (2010) Differential sodium and potassium transport selectivities of the rice OsHKT2;1 and OsHKT2;2 transporters in plant cells. Plant Physiol 152:341-355

Yeo AR (1999) Predicting the interaction between the effects of salinity and climate change on crop plants. Sci Hortic 78:159-174

Yeo AR, Flowers TJ (1986) The physiology of salinity resistance in rice (Oryza sativa L.) and a pyramiding approach to breeding varieties for saline soils. Aust J Plant Physiol 13:75-91

Yeo AR, Caporn SJM, Flowers SA (1985) The Effect of Salinity upon Photosynthesis in Rice (Oryza sativa L.): Gas Exchange by Individual Leaves in relation to their Salt Content. J Exp Bot 36:1240-1248

Yeo AR, Yeo ME, Flowers TJ (1987) The contribution of an apoplastic pathway to sodium uptake by rice roots in saline conditions. J Exp Bot 38:1141-1153

Yeo AR, Yeo ME, Flowers SA, Flowers TJ (1990) Screening of rice (Oryza sativa L.) genotypes for physiological characters contributing to salinity resistance, and their relationship to overall performance. Theor Appl Genet 79:377-384

Zeier J, Goll A, Yokoyama M, Karahara I, Schreiber L (1999) Structure and chemical composition of endodermal and rhizodermal/hypodermal walls of several species. Plant Cell Environ 22:271-279

Zhu JK (2002) Salt and drought stress signal transduction in plants. Annu Rev Plant Physiol Plant Mol Biol 53:247-273

Zhu JK, Liu JP, Xiong LM (1998) Genetic analysis of salt tolerance in Arabidopsis: Evidence for a critical role of potassium nutrition. Plant Cell 10:1181-1191

Zimmermann HM, Hartmann K, Schreiber L, Steudle E (2000) Chemical composition of apoplastic transport barriers in relation to radial hydraulic conductivity of corn roots (Zea mays L.). Planta 210:302-311

Zolla G, Heimer YM, Barak S (2010) Mild salinity stimulates a stress-induced morphogenic response in Arabidopsis thaliana roots. J Exp Bot 61:211-224

doi:10.1186/1939-8433-5-11

Cite this article as: Horie et al:: Salinity tolerance mechanisms in glycophytes: An overview with the central focus on rice plants. Rice 2012 5:11. 